

IFN Working Paper No. 1068, 2015

\title{
Private Equity, Layoffs, and Job Polarization
}

Martin Olsson and Joacim Tåg 


\title{
Private Equity, Layoffs, and Job Polarization*
}

\author{
Martin Olsson \\ Research Institute of Industrial Economics (IFN) and IFAU \\ Joacim Tåg \\ Research Institute of Industrial Economics (IFN)
}

April 2015

\begin{abstract}
Although private equity firms are often criticized for layoffs, little evidence exists regarding which employees lose their jobs and why. We argue that explanations for the job polarization process can also explain layoffs after buyouts. Buyouts reduce agency problems, which triggers automation, offshoring, and tougher bargaining with labor unions. We show that workers in less productive firms who perform routine or offshorable job tasks are more likely to lose their jobs. The opposite trend holds for workers who perform non-routine or non-offshorable job tasks. Moreover, workers who belong to aggressive labor unions are more likely to lose their jobs.
\end{abstract}

Keywords: Employment, job polarization, labor unions, private equity buyouts, leveraged buyouts, offshoring, restructuring, task-biased technological change, unemployment.

JEL Codes: G32; G34; J60.

${ }^{*}$ The authors can be reached at martin.olsson@ifn.se and joacim.tag@ifn.se. We are grateful to the Marianne and Marcus Wallenberg Foundation, the Jan Wallander and Tom Hedelius Foundation, the NASDAQ OMX Nordic Foundation and Vinnova for financial support. We thank Ramin Baghai, Nils Gottfries, Andrea Ichino, Matti Keloharju, Gueorgui Kolev, Josh Lerner, Erik Lindqvist, Alexander Ljungqvist, Daniel Metzger, Louise Nordström, Paul Oyer, Lars Persson, Jörg Rocholl, Peter Skogman Thoursie, Martin Strieborny, Per Strömberg, Helena Svaleryd, seminar participants at EEA, EFA, EIEF, IFN, KTH, NHH, Lund University, Ratio, SIFR, Koc University, Gothenburg University, University of Illinois at Urbana-Champaign for excellent comments and suggestions. Thanks also to Selva Baziki, Aron Berg, Mathias Ekström, Axel Gottfries, Dina Neiman, Hanna Thunström, and Nina Öhrn for exceptional research assistance. This paper replaces our earlier working paper with the title "Private Equity and Employees". 


\section{Introduction}

Every day, an increasing number of workers find themselves working for private equity-backed firms. During the period from 1985 to 2006, private equity firms bought firms in the United States at a staggering annual rate of $1 \%$ of the total stock market value. In 2014, private equity-backed firms employed more than 7.5 million workers in the United States alone. Many workers fear that a buyout could result in job loss. Private equity firms are often portrayed by labor unions and the media as vultures that cut costs through layoffs. ${ }^{1}$ However, few academic studies have documented the harmful effects of buyouts on employment.

Layoffs after buyouts do happen, and these layoffs are partly responsible for the negative public view of private equity buyouts. One reason for the difference between the public view and the academic evidence is that most academic studies have focused on net employment. These studies provide important insights regarding the way private equity buyouts affect overall employment in targeted firms. However, these studies provide little evidence about what happens to workers who are employed at a firm just before a buyout. For example, zero effects on net employment from one year to the next could mean that $10 \%$ of the existing workers were laid off and quickly replaced with new hires. What are the effects of buyouts on existing workers? Do some workers have more reason to fear for their jobs than others? If so, why?

The goal of this paper is to provide new insights into these questions. We argue that layoffs in private equity buyouts can be understood through the lens of the job polarization process. Job polarization means that employment in low- and high-skilled jobs has increased and employment in medium-skill jobs has decreased. At least three explanations have been given for this "hollowing out of the middle class": the automation of routine job tasks due to technological development, the globalization of product and labor markets, and the weakening of labor unions over time. ${ }^{2}$

We argue that these three explanations also explain layoffs in private equity buyouts. The reason is that private equity firms are effective in reigning in rampant agency problems in firms, as noted

\footnotetext{
${ }^{1}$ See, for example, FSA (2008), ITUC (2007), or PSE (2007) for criticism by labor unions. For more on the media debate, see, for example, The Economist, Jan 28th 2012, "Monsters, Inc?"; The Economist, Jan 28th 2012, "Bain or blessing?"; Financial Times, Jan 10th 2012,"Video attacks Romney's record"; Financial Times, Jan 13th 2012, "The bane of Bain"; or The Wall Street Journal, Jan 9th 2012, "Romney at Bain: Big Gains, Some Busts".

${ }^{2}$ See, for example, Autor (2010), who also mentions declining minimum wages as one explanation. For recent evidence of job polarization in the United States and, more generally, in developed countries, see, for example, Autor et al. (2003), Autor et al. (2006, 2008), Blinder and Krueger (2013), Autor and Dorn (2013), and Goos et al. (2014). Acemoglu and Autor (2011) provide a survey.
} 
by Jensen (1989). Agency problems allow managers to avoid difficult and unpopular decisions. These decisions include green-lighting investments in automation and offshoring production as well as exhibiting strength when negotiating with labor unions. Although entrenched managers may procrastinate regarding these decisions, these decisions are crucial for improving productivity and profitability. Thus, firms in which these decisions have been delayed are prime targets for buyouts. Consequently, workers in routine jobs or offshorable jobs and workers who are entrenched because of ties to aggressive labor unions are prime targets for layoffs after buyouts.

For empirical evidence regarding our claim, we look to Sweden. Sweden is a unique testing ground for this argument for several reasons. Detailed data on all workers in the country are available for 22 years, and workers only qualify as leaving the data pool by dying or moving abroad. Thus, it is possible to find workers who were employed in target firms just before the buyout and to follow them over time to see whether they enter unemployment. In addition, accounting data are available for all public and private firms. The raw dataset contains 2.6 million firm-year observations and 72 million worker-year observations for the period from 1999 to 2008. Because private equity firms do not randomly select targets, selection bias is a central concern, and the availability of comprehensive data means that we can rely on matching methods and differencein-difference regressions to mitigate selection biases. ${ }^{3}$ Finally, Sweden has an active private equity market, job polarization has occurred during the last several decades, and union membership is high. ${ }^{4}$ These features ensure that there are enough buyouts for statistical analysis and that private equity firms could profit by reorganizing targeted firms through automation, offshoring, and a tougher stance on labor unions.

Our analysis focuses on unemployment incidence before and after the buyout. Using standard measures of the routine intensity of job tasks, the offshorability of job tasks, and union aggressiveness, we observe the following:

1. Workers in routine jobs are $63 \%$ more likely and workers in non-routine jobs are $16 \%$ less likely to become unemployed after a buyout compared to control workers. These effects are

\footnotetext{
${ }^{3}$ Matching methods are particularly useful when many observable characteristics and potential controls are available (Heckman et al., 1997).

${ }^{4}$ Lerner et al. (2008) shows that in 2006, Sweden had the highest level of private equity investments to gross domestic product in all of Europe. Adermon and Gustavsson (2014) provides evidence of job polarization in Sweden, and Larsson (2012) provides union membership numbers, which have hovered between $72 \%$ and $85 \%$.
} 
only present for workers in buyout targets that lag behind their peers in productivity ex ante-that is, in firms that likely are in need of reorganization.

2. Workers in offshorable jobs are $56 \%$ more likely and workers in non-offshorable jobs are $13 \%$ less likely to become unemployed after a buyout compared to control workers. As for routine and non-routine jobs, these effects are only present for workers in buyout targets that lag behind their peers in productivity ex ante. Despite the similar magnitudes of the estimates, offshorability is a separate measure from routine intensity. The correlation between these two measures in our sample is only 0.3 .

3. Entrenched workers are $23 \%$ more likely to become unemployed relative to control workers after a buyout. Entrenched workers are workers in firms with ex ante low leverage relative to their peers and blue-collar workers who tend to be affiliated with aggressive labor unions. ${ }^{5}$

Consistent with these worker-level results, we find that the target firms that lag behind their peers ex ante in productivity tend to leave net employment unchanged, but they increase productivity by $11 \%$ and profitability by $5 \%$. Firms that ex ante have higher productivity than their peers, however, see net employment increase by $13 \%$, but productivity and profitability remain unchanged. Taken together, these results suggest that two types of buyouts take place in our sample. Firms with low productivity relative to their peers are targets of buyouts that focus more on restructuring, as documented by Davis et al. (2014) for the United States, whereas while firms with high ex ante productivity relative to their peers are targets of buyouts that focus more on growth, as documented in France by Boucly et al. (2011).

Although estimating the causal effects of a buyout is inherently difficult, we believe that our results present a compelling case that layoffs after buyouts can be understood through the lens of the job polarization process. Evidence from surveys confirms this conclusion. During the spring of 2009, the Swedish labor union Unionen asked its union chairmen at private equity backed firms what changes had occurred since changing ownership. Approximately $62 \%$ of the chairmen answered that investments in new markets/products/services had occurred, and approximately $27 \%$ answered

\footnotetext{
${ }^{5}$ The ex ante leverage of the firm relative to its peers matters because a lower ex ante leverage means a greater change in leverage due to the buyout and a greater change in the bargaining power of the firm. Extensive labor and finance literature has documented that the capital structures of firms are closely related to the bargaining powers of unions (see, for example, Rosett (1990), Bronars and Deere (1991), Matsa (2010) and Benmelech et al. (2012)).
} 
that the outsourcing of operations had occurred. When asked what problems they thought were associated with private equity company ownership, approximately $56 \%$ agreed to a high degree or to some degree that cooperation with trade unions had declined. ${ }^{6}$

Our paper contributes to the literature on private equity buyouts and employment. Most published studies regarding this topic focus on net employment. Recent evidence on the effects of buyouts on employment in the United States suggest that private equity firms catalyze the creative destruction process and improve productivity. For example, Davis et al. (2014) show large effects on gross job creation and destruction. The firm-level results of modest net job losses reported by these authors correspond with those of other papers regarding buyouts in the United States, such as Kaplan (1989), Muscarella and Vetsuypens (1990), and Lichtenberg and Siegel (1990). ${ }^{7}$ Our results correspond to those of Davis et al. (2014), which indicate that private equity firms catalyze the creative destruction process and improve productivity. However, we also show that the reorganization activities that private equity firms undertake can result in layoffs that can be explained by automation, offshoring, and tougher bargaining with labor unions. Thus, our results shed new light on how buyouts affect labor. We are aware of two other worker-level studies in the literature, but these studies do not analyze explanations for layoffs. Amess et al. (2007) analyze management buyouts in the United Kingdom and show that buyouts reduce the number of hierarchical tiers and that craft and skilled service employees are most likely to receive reduced supervision and increased discretion. In addition, Agrawal and Tambe (2014) focus on how IT investments by private equity firms affect the careers of workers complementary to IT investments.

Furthermore, our results shed new light on the broader debate between value capture and value creation in buyouts. This debate began in early studies on buyouts. For example, Jensen (1989) argued that buyouts are a superior organizational form that creates value. This view is often compared with the claim presented by Shleifer and Summers (1988), which states that hostile takeovers capture value from workers and other stakeholders instead of creating it. Existing empirical evidence shows that buyouts are followed by productivity improvements, that there are few negative

\footnotetext{
${ }^{6}$ See Tjärnback (2009).

${ }^{7}$ There are also studies on buyouts from other countries. Evidence from the United Kingdom also suggests decreases in employment growth, but the effects appear to be weaker for more recent buyouts (Wright et al., 1992; Amess and Wright, 2012). In Sweden, employment remains unchanged (Bergström et al., 2007), but in France, private equity firms appear to provide capital to capital-constrained firms and generate positive employment growth (Boucly et al., 2011). Kaplan and Strömberg (2009) and Tåg (2012) provide summaries of the literature on private equity buyouts and employment.
} 
long-term investment effects and few tax gains and that firm-level employment generally does not decrease. $^{8}$ Thus, the standard conclusion is often that private equity firms create value, which corresponds to the findings of Jensen (1989). We agree that this conclusion holds on average, but we add that value creation does not rule out value capture. Our results show value capture from the subgroups of workers who are more likely to be laid off. Simultaneously, we show that other subgroups of workers are less likely to be laid off and that productivity and profitability gains occur for firms that are less productive than their peers, which is consistent with value creation. ${ }^{9}$

Finally, our paper contributes to the broader literature on finance and labor and to the job polarization literature. Our results on tougher bargaining with labor unions as an explanation for layoffs are consistent with studies that have documented a robust link between a firm's financial policy and labor outcomes. ${ }^{10}$ In addition to providing new empirical support for this link, we contribute by showing how financial intermediaries in the form of private equity firms can shape the labor policies of firms. Specifically, our results suggest that an active private equity market could accelerate the process of job polarization in a country. Moreover, the job polarization literature has typically focused on examining the long-run changes in wages and employment within and across countries. ${ }^{11}$ Our paper provides novel evidence that changes in the ownership of firms could be an important channel through which the job polarization process happens.

Whether our results generalize beyond the borders of Sweden is an open question. However, the following observations suggest that they do. ${ }^{12}$ First, the Swedish private equity market is characterized by a substantial presence of international private equity firms and the same types of

\footnotetext{
${ }^{8}$ See, for example, Kaplan (1989), Lichtenberg and Siegel (1990), Amess (2002), Amess (2003), Harris et al. (2005) and Davis et al. (2014) for evidence on productivity, Lerner et al. (2011) for evidence on long-run investments, and Jenkinson and Stucke (2011) for evidence on taxes.

${ }^{9}$ Because we observe moves to unemployment for workers, our results provide information regarding welfare losses and value capture in buyouts. As noted by Shleifer and Summers (1988), "to see if the parties that lose in association with the acquired firm suffer wealth losses, one must trace their subsequent employment." If workers simply move to other forms of employment, wealth losses may not be large. However, if workers move to unemployment, they are far worse off. Workers entering unemployment often face wage cuts after accepting a new job offer, consumption reductions, and decreased happiness. See, for example, Farber (2005), Katz and Mayer (1990), Jacobson et al. (1993), Gruber (1997), and Di Tella et al. (2001).

${ }^{10}$ See, for example, Rosett (1990), Bronars and Deere (1991), Matsa (2010), Benmelech et al. (2012), and Graham et al. (2013).

${ }^{11}$ See, for example, Blinder and Krueger (2013), Autor and Dorn (2013), and Goos et al. (2014) for recent studies. In addition, Acemoglu and Autor (2011) provides a recent survey. Initially, the job polarization process was explained by skill-biased technological change, that is, how new technologies affected high- and low-skilled workers. Instead, recent work emphasizes the importance of the job task and provides evidence that the nature of the job task - whether it is routine and/or offshorable - matters more than the skill level of the worker.

${ }^{12}$ See Appendix A for a more detailed discussion of buyouts in Sweden in comparison to buyouts elsewhere.
} 
transactions that occur abroad occur in Sweden. Second, the Swedish private equity market evolved partly in response to the wave of buyouts in the United States and has resulted in the development of several Swedish private equity firms that operate internationally. Third, the holding periods, performance, and outcomes of the target firms in Swedish buyouts are similar to those in other countries. Fourth, the evidence of firm-level outcomes that we present in Section 6 suggests that the firm-level outcomes in Sweden are comparable to those in other countries. Finally, when the OECD ranked the overall employment protections in member countries and other selected nonOECD countries in 2004, Sweden was ranked as having the seventh-strongest protection among 30 countries (OECD, 2004). Thus, Sweden has quite strong employment protection regulations. ${ }^{13}$ However, if employment protection regulations in Sweden are important, any results concerning more layoffs that we find are likely to represent a lower bound for the effects of buyouts on workers.

\section{Data and Empirical Strategy}

\subsection{Data Sources}

Statistics Sweden. Our main source of data is Statistics Sweden's LISA database, which contains individual-level data from 1990 to 2011. LISA is a longitudinal matched employer-employee database that includes every person older than 15 that is registered as living in Sweden. The LISA database merges data from different government registers, including population registers, tax records, and statistical surveys. Because LISA is based on the government registration of inhabitants in Sweden, an individual only exits the database by dying or moving to another country. The database contains individual identifiers that enable us to track people over time and independent of labor market status. From LISA, we extract annual information on age, gender, education, occupation (available for 2001-2011), labor income, firm and establishment affiliation, industry, the geographical location of establishment affiliation, and the number of days registered as unemployed. We calculate the firm-specific tenure by observing work histories from 1990 to 2011, and we construct a skill dummy by assigning a value of one to people with at least two years of post-secondary

\footnotetext{
${ }^{13}$ Despite differences in labor market institutions, Lazear and Shaw (2009) reported surprising similarities in how labor markets function across Scandinavian countries and Belgium, France, Germany, Italy, the Netherlands, and the United States. In all these countries, Lazear and Shaw (2009) found large wage variations within the firms, growth in the across- and within-firm differences in wages with time, and consistent mobility patterns in high-wage firms with low turnover rates and in large firms with higher wages and lower entry and exit rates.
} 
education. Table A1 provides details regarding these variables. We identify a firm and its workers the year before the announcement of the buyout. We then follow workers four years before and four years after. Because the register data cover persons older than 15, we restrict the sample to individuals who are older than 19 or younger than 62 the year before the buyout announcement (the retirement age is 65)

Swedish Companies Registrations Office. The firm data we use are from the annual accounts collected by the Swedish Companies Registrations Office (SCRO). Swedish law requires all limited liability firms to deliver annual accounts to the SCRO. ${ }^{14}$ To ensure the quality of the data, external auditors check the filed accounts of all firms. Non-compliance or submitting incorrect information results in liquidation and unlimited liability for board members. Regarding the annual accounts, we have information from 1998 to 2010 for the name of the firm, the firm identifier, sales, fixed assets, value added per employee, debt to assets, return on assets, and the group structure of the firms. We supplement the data with firm-level variables that are aggregated from the individual-level data in LISA. These variables include firm size, firm size growth, number of establishments, hirings and separations, a diversification dummy, firm age, average worker age, standard deviation of worker wage, average worker age, average worker tenure, industry and location. Table A1 provides details regarding these variables.

Capital $I Q$ and Bergström et al. (2007). We obtain information on the buyouts undertaken between 1999 and 2008 in Sweden from the Capital IQ database and Bergström et al. (2007). We apply the same selection criteria as Strömberg (2008) to the transactions in Capital IQ, add the buyouts that were identified by Bergström et al. (2007) that were not in Capital IQ, and remove the secondary buyouts. ${ }^{15}$ We remove the secondary buyouts because the explanations for layoffs we study apply to the first time a company undergoes a buyout. We match the buyout information with the firm data from the SCRO based on company names. The SCRO data has firm identifiers that allow us to map the buyouts to the LISA database. Because buyouts often occur in holding companies, we also mark subsidiaries as targets. When marking subsidiaries, we use the group structure from the SCRO for one year before the buyout announcement to ensure that the group structure is unaffected by the buyout.

\footnotetext{
${ }^{14}$ Årsredovisningslag [1995:1554] 8 sec. 3 and Bokföringslag [1999:1078] 6 sec. 2.

${ }^{15}$ Appendix B describes the exact procedure we use. We thank Clas Bergström for providing us with the data matched with the legal firm identifiers.
} 


\subsection{Empirical Strategy}

The main econometric concern for us is selection; private equity firms do not choose targets randomly. Thus, buyout targets differ from other firms regarding their observable and unobservable characteristics. Selection bias occurs if these characteristics are correlated with unemployment incidence for workers. Because we lack an experiment that randomly assigns buyouts to firms, it is important to mitigate selection bias. Our approach is to combine propensity score matching (Rosenbaum and Rubin, 1983; Heckman et al., 1997, 1998) with a difference-in-difference estimator. Propensity score matching mitigates biases that arise from selection based on observable characteristics, and the difference-in-differences estimator deals with unobserved time-invariant group effects and common time effects. Although we cannot make causal claims, Smith and Todd (2005) show that combining propensity score matching with difference-in-difference regressions performs well in mitigating selection biases. Moreover, propensity score matching is particularly useful when there are many potential controls, which is the case in our setting (Heckman et al., 1997).

We model the unemployment incidence for worker $i$ in firm $f$ in group $g$ at time $t$ as

$$
Y_{i f g t}=\alpha+\delta P O S T_{t}+\gamma L B O_{g}+\beta\left(P O S T_{t} \times L B O_{g}\right)+\theta X_{i}+\pi F_{f}+\lambda_{r}+\epsilon_{i f g t} .
$$

The dependent variable is the unemployment incidence, $Y_{i f g t}$. This variable is one if an individual is registered as unemployed for one or more days during the year. The $P O S T_{t}$ variable is one for the year of the buyout announcement and all years after. The $L B O_{g}$ variable is one for the workers in the treated firms and zero for the workers in matched control firms. We normalize time so that time zero is the year before the buyout announcement. The term $\lambda_{r}$ represents the year dummies. ${ }^{16}$

The treatment group consists of workers employed at the target firms a year before the buyout announcement. ${ }^{17}$ We analyze these pre-existing workers before and after the buyout regardless of whether they were employed at the same firm. Because workers only leave the sample by moving abroad or dying, we do not need to worry about compositional changes in the treatment and control

\footnotetext{
${ }^{16}$ The subindex $r$ represents the actual year $(r=1994,1995, \ldots, 2011)$, in contrast with the subindex $t$, which represents the normalized time period $(t=-4,-3, \ldots, 4)$.

${ }^{17}$ Nine out of ten buyouts in our sample are closed within the same year that they are announced.
} 
groups. ${ }^{18}$ Thus, the coefficient $\beta$ captures the intention-to-treat effect. The intention-to-treat effect is a reduced-form effect and here measures the average change in unemployment incidence for pre-existing workers over a four-year post-buyout period.

We include the individual controls $X_{i}$ and the firm controls $F_{f}$ in Equation 1 to increase efficiency and to control for common industry and region effects. The individual controls are age, age squared, gender, annual labor income at $t=0$, a skill dummy taking the value of one for workers with at least two years of post-secondary education, tenure at $t=0$, and five dummies for whether a worker has at least one day of unemployment at time $t=0, t=-1, t=-2, t=-3$, and $t=-4$. The firm controls are size at $t=0$, size squared at $t=0$, size growth from $t=-1$ to $t=0$, firm age at $t=0$, firm age squared at $t=0$, industry affiliation at $t=0$, and geographical location at $t=0$.

The identifying assumption for the coefficient $\beta$ to have a causal interpretation is that the treated and control groups have parallel trends in the absence of treatment. It is not possible to test this assumption because we cannot observe the counterfactual outcomes. However, we can assess the plausibility of the assumption by comparing trends in unemployment incidence before treatment. Historical parallel trends indicate that shocks, at least in the past, have affected the two groups in a similar way.

On inference, two issues arise. First, the correlation between workers in a firm can result in standard errors that are too small (Moulton, 1986). We can correct for intraclass correlation by clustering the standard errors at an appropriate level. Second, matching on an estimated propensity score can result in standard errors that are too small or too large (Abadie and Imbens, 2012). Currently, no consensus exists regarding how to simultaneously deal with these two concerns. Thus, we alert the reader to the presence of the second issue and deal with the first issue by clustering the standard errors at the firm and the local labor market levels. By clustering at the firm and the local labor market levels, we account for the fact that the workers in our data can flow between firms and in and out of unemployment.

\footnotetext{
${ }^{18}$ Note that the treatment effect on the treated cannot be recovered if non-random attrition before the buyout occurs. Because workers can leave the firm before the buyout takes place, the intention-to-treat effect is smaller than the average treatment effect on the treated. However, as noted by Angrist and Pischke (2009), the significance level of the reduced-form effect and the treatment effect on the treated are asymptotically the same.
} 


\subsection{Creating the Control Group}

To create the control group, we perform matching at the firm level using one-to-one matching without replacement. ${ }^{19}$ The matching process finds a control firm for each treated firm that is statistically the same as the treated firm. The details and motivations for the matching procedure are available in Appendix C. We use all limited liability firms in Sweden as potential controls with one exception: we exclude firms that were targeted for mergers or acquisitions based on data from the BvD Zephyr database. We exclude the merger or acquisition targets because the explanations for layoffs that we study rely on the counterfactual that the firm targeted for a buyout remains private and is not acquired by another firm.

We base the variables we include in the propensity score estimation on previous literature and on the theory behind the explanations for layoffs that we study. The opportunity for automation, offshoring, and gains from bargaining with labor unions should be more important in firms that are plagued by agency problems. Agency problems should be more common in older firms that are less productive and have ceased growing as well as in diversified firms and in firms with low wage dispersion, high free cash flows, low leverage, and where entrenched workers are paid high wages and have longer tenures in the firm. ${ }^{20}$ Thus, we include fixed assets, sales, firm age, value added per employee, firm growth, whether a firm has establishments in several industries, the standard deviation of worker wages, return on assets, debt to assets, and average worker wage in the propensity score estimation. In addition, Davis et al. (2014) and Boucly et al. (2011) use control firms of the same size and age and from the same year and industry. ${ }^{21}$ We agree that these characteristics are important and match the predicted propensity scores within the strata of these variables.

\subsection{The Final Sample}

Column 1 in Table 1 displays the summary statistics on the buyouts in our final sample. The final sample contains 351 buyouts matched to control firms. This is $69 \%$ of the buyouts that we

\footnotetext{
${ }^{19}$ Table A3 in the Appendix shows that our main results are similar if we use one-to-four propensity score matching.

${ }^{20}$ These hypotheses are based on, among others, Jensen (1986), Shleifer and Summers (1988), Jensen (1989), Perotti and Spier (1993), Kaplan and Strömberg (2009), and Cronqvist et al. (2009).

${ }^{21}$ Davis et al. (2014) performed a cell match for the industry, size, age, multi-unit status, and year of the buyout transaction, whereas Boucly et al. (2011) used industry, firm size and return on assets.
} 
extracted from the Capital IQ database and Bergström et al. (2007). For comparison, Davis et al. (2014) matched $65 \%$ of the buyouts from Capital IQ to firm records, and Boucly et al. (2011) matched $70 \%$.

The buyouts in our final sample resemble the buyouts from Capital IQ that we were able to match to firm identifiers (Column 3). Cross-border transactions, corporate divestitures, and management buyouts are the most common types of transactions, even if the transactions are weighted by employment (Column 2). The average transaction value in our sample is $\$ 193$ million USD, and the number of buyouts is increasing over time. The transaction types, values, and time trends in Sweden are similar to buyouts in the United States (Column 4), the United Kingdom (Column 5), and France (Column 5). In all countries, the majority of all transactions are corporate divestitures or management buyouts. The major difference is that more than $30 \%$ of all buyouts in Sweden are cross-border transactions. Average transaction values are lower in Sweden than in the United States, but they are comparable to those in the United Kingdom and France. In all four countries, the number of buyouts increased by more than $60 \%$ between 1999 and $2008 .^{22}$

\subsection{Assessing the Control Group}

The matching procedure succeeds in ironing out observable differences between the treated and control firms. Table 2 presents the average worker- and firm-level characteristics for the treated group (Column 1), the matched control group (Column 2), and a random sample of Swedish firms (Column 3). Column 4 presents the average difference between the treated and control group. The treated and control firms and workers resemble each other in all observable dimensions. Column 5 presents the average difference between the treated group and a random sample of firms and their workers. The firm characteristics are significantly different between the treated firms and the randomly selected firms, indicating that the buyouts are not randomly drawn from the population of firms. ${ }^{23}$

In addition, the matching procedure produces a control group of workers with a pre-treatment trend in unemployment incidence that is parallel to that of the treated group of workers. Figure

\footnotetext{
${ }^{22}$ See Appendix A for a more detailed discussion of buyouts in Sweden in comparison to buyouts elsewhere.

${ }^{23}$ The average firm size growth is high because several firms in our sample were started between $t=-1$ and $t=0$. This result likely occurred because of the large share of buyouts that are corporate divestitures. These firms are coded as having a growth rate of $200 \%$ (our growth measure is based on Davis et al. (2014)). The median growth size is $6.4 \%$ for the treated firms, $8.0 \%$ for the control firms and $0.0 \%$ for random firms.
} 
1 plots the average unemployment incidence for treated and control workers. All workers are employed at $t=0$, so the unemployment incidence decreases until $t=0 .{ }^{24}$ Before the buyout announcement at $t=1$, the trends in unemployment incidence are parallel. Although this does not indicate that our identification strategy works, it does indicate that shocks have affected the groups in a similar way before the buyout announcement, which is encouraging.

After the buyout announcement, the trends in unemployment incidence remain parallel. This result suggests that on average, buyouts do not affect unemployment incidence for workers. The estimates presented in Table 3 confirm the null result. The estimated treatment effect in Column 1 corresponds to Figure 1 and is economically and statistically insignificant. Column 2 adds individual covariates, and Column 3 adds firm covariates. The inclusion of covariates improves the explanatory power of the model - the $R^{2}$ increases from $0.3 \%$ to $27.8 \%$ - but the estimated treatment effect remains statistically insignificant and economically small.

A treatment effect close to zero does not rule out heterogeneous treatment effects. Heterogeneous treatment effects is the topic of the next three sections.

\section{Automation}

\subsection{Motivation}

Investments in productivity-enhancing technologies after buyouts could explain layoffs. Buyouts can trigger these investments if previous management avoided undertaking them because of widespread agency problems in the firms. However, buyouts not only reduce agency problems by concentrating ownership but also relax the financial constraints of the target firms and improve their management practices, which can spur investments (Boucly et al., 2011; Bloom et al., 2009). Davis et al. (2014) show that private equity-backed firms increase productivity by shutting down less productive establishments and opening up more productive ones. This result is consistent with firm-level studies that have shown productivity improvements after a buyout. ${ }^{25}$ Moreover, Boucly et al. (2011) show that capital expenditures increase after buyouts, and Agrawal and Tambe (2014) present

\footnotetext{
${ }^{24}$ Average unemployment incidence does not reach zero at $t=0$ because Statistics Sweden measures the employment status on the first of November each year. Thus, workers could be unemployed before or after that date during a year.

${ }^{25}$ See, for example, Kaplan (1989), Lichtenberg and Siegel (1990), Amess (2002), Amess (2003), Harris et al. (2005) or Davis et al. (2014).
} 
evidence that is consistent with higher investments in information technologies after buyouts.

Investments in productivity-enhancing technologies are likely to affect some workers more than others. Recent evidence suggests that new technologies have reduced demand for workers performing routine tasks due to automation. However, the demand for workers who perform non-routine tasks increases because these tasks are complementary to the new technologies (Acemoglu and Autor, 2011; Autor and Dorn, 2013; Goos et al., 2014). Goos et al. (2014) provide evidence from 16 European countries that routine-biased technological change is important for explaining job polarization. In addition, routine-biased technological change has affected Sweden. Adermon and Gustavsson (2014) find that task-biased technological change has been increasing in Sweden since the 1990s, and Nilsson Hakkala et al. (2014) find that acquisitions by multinational firms increases the labor demand for non-routine job tasks.

Thus, automation after buyouts could be one explanation for layoffs. If this explanation is important, we expect positive treatment effects for workers performing routine job tasks. The tasks these workers perform are substitutes for technological upgrades. In addition, we expect negative treatment effects for workers who perform non-routine tasks because the new technologies are complementary to the tasks that these workers perform. Finally, this pattern should be stronger for buyouts of firms that lag behind their peers in productivity; such firms are more likely to be in need of technological upgrades.

\subsection{Results}

For evidence, we begin by estimating Equation 1 for subsamples based on the routine intensity of the job tasks that workers perform at $t=0$. We have occupation information for workers from 2001 onwards. Thus, we restrict our attention to buyouts that were announced after 2001 and rely on the RTI index from Goos et al. (2014) to classify occupations. Autor et al. (2003) and Autor et al. (2006, 2008) developed the RTI index, and Goos et al. (2014) mapped it with ISCO-88 codes, which can be mapped to the SSYK codes for occupations used by Statistics Sweden. ${ }^{26}$

Panel A in Table 4 displays the results. Column 1 shows the estimated treatment effect for all workers in the buyouts announced after 2001. Similar to the estimated treatment effect for the whole sample period, the effect is small and statistically insignificant. Column 2 displays the

\footnotetext{
${ }^{26}$ Table A4 in the appendix outlines the mapping procedure we used.
} 
estimated treatment effect for workers in routine occupations. The estimated treatment effect is positive, but it is imprecisely estimated with a t-value of 1.35 . Column 3 displays the estimated treatment effect for workers in non-routine occupations. This estimate suggests a 1.2 percentage point reduction in average unemployment incidence for workers in non-routine occupations. The estimated reduction is statistically significant with a t-value of -2.23 . The reduction is economically meaningful and corresponds to a 9.7\% average decrease in unemployment incidence in the postperiod. These point estimates are in line with the notion that investments in automation can explain layoffs.

For additional evidence, Panels $\mathrm{B}$ and $\mathrm{C}$ in Table 4 break up the sample using the ex ante productivity of the target firms. We define firms as having low productivity if they have a value added per employee that is below the median in the two-digit industry in which they operate. Otherwise, we define them as high-productivity firms. We measure their relative productivity at $t=0$, i.e., the year before the buyout announcement.

Panel B displays the results for routine and non-routine workers in ex ante low-productivity firms. Column 1 reveals that the treatment effect for workers in these firms is generally not statistically significant. However, as expected, the estimated treatment effects of routine and non-routine workers are more pronounced than the estimates in Panel A. Column 2 displays the estimated treatment effect for routine workers. These workers experience a 6.6 percentage point increase in unemployment incidence. This effect is statistically significant with a t-value of 3.18 and corresponds to a $62.9 \%$ increase in unemployment incidence. The estimated treatment effect for non-routine workers is a 2.4 percentage point decrease, which is displayed in Column 3. This effect is statistically significant with a t-value of -2.93 and corresponds to a $15.7 \%$ decrease in unemployment incidence. Thus, we observe economically meaningful changes in unemployment incidence for both groups of workers in this subsample of firms. Panel C displays the results for routine and non-routine workers in ex ante high-productivity firms. Overall, we find no statistically significant effects (Column 1) for routine workers (Column 2) or non-routine workers (Column 3).

These results provide new insights regarding how buyouts affect workers. Existing evidence shows that productivity improvements occur after buyouts. ${ }^{27}$ In addition, Agrawal and Tambe

\footnotetext{
${ }^{27}$ See, for example, Kaplan (1989), Lichtenberg and Siegel (1990), Amess (2002), Amess (2003), Harris et al. (2005) or Davis et al. (2014).
} 
(2014) provide evidence that IT workers after buyouts in the United States are employed for a longer

amount of time over their careers. Based on this evidence, it is easy to conclude that productivity improvements benefit workers, particularly because few studies have indicated declines in the net employment levels of firms following buyouts. The evidence we present in Table 4, however, suggests that buyouts benefit non-routine workers at the expense of routine workers. This finding casts a more nuanced light on how productivity improvements affect workers.

\section{Offshoring}

\subsection{Motivation}

The second explanation for layoffs after buyouts relates to offshoring. Buyouts result in the alignment of incentives between managers and owners and reduce agency problems in firms (Jensen, 1989; Kaplan, 1989; Kaplan and Strömberg, 2009). This alignment can result in a greater focus on cutting costs and focusing activities. Edgerton (2012) presents evidence indicating that private equity-backed firms have $40 \%$ fewer private jets than similar public firms. In addition, Davis et al. (2014) provide evidence of shrinkage, and the removal of pre-existing establishments is consistent with divesting non-core activities. Lerner et al. (2011) present evidence indicating that private equity firms tend to focus their patent portfolios, and Harris et al. (2005) notes that one explanation for the occurrence of productivity improvements and reductions in labor intensity after buyouts could be the outsourcing of intermediate goods and services.

An increased focus on cutting costs and divesting non-core activities can result in offshoring. Offshoring refers to moving parts of the production chain abroad. Historically, offshoring was a phenomenon that was only common in the manufacturing industry. However, the rise of available educated service workers in Asia has led to the spread of offshoring to other sectors of the economy (Blinder, 2006; Tambe and Hitt, 2012). Blinder and Krueger (2013) indicates that approximately $25 \%$ of all jobs in the Unites States can be performed from abroad. As noted by Goos et al. (2014) and Blinder and Krueger (2013), not all offshorable job tasks are routine, and not all non-offshorable job tasks are non-routine. Consequently, it is important to treat the offshorability of job tasks as distinct from the routine intensity of job tasks.

Cost-cutting and focusing activities through offshoring could provide one explanation for layoffs 
after buyouts. If this explanation is valid, we can expect positive treatment effects on offshorable workers as private equity firms move the tasks that these workers perform abroad. In addition, we expect negative treatment effects on non-offshorable workers because offshoring allows private equity-backed firms to focus on non-offshorable tasks. Finally, as with routine intensity, we hypothesize that this pattern should be stronger for the buyout of firms that lag behind their peers in productivity. Such firms are more likely to require cost cutting and an additional focus on improving productivity.

\subsection{Results}

As with automation, offshoring affects some workers more than others. Whether a job is offshorable depends on the nature of the task. For instance, the job of a truck operator cannot be offshored. In contrast, the work of call center operators is easy to offshore. To classify occupations as offshorable or non-offshorable, we rely on Goos et al. (2014). Goos et al. (2014) provide a classification of occupations that are normalized and mapped to ISCO-88 codes based on Blinder and Krueger (2013). In addition, Blinder and Krueger (2013) code occupations based on the opinions of professionals regarding how easy it would be to offshore the occupation. Table A4 in the Appendix details the categorization of occupations into offshorable/non-offshorable and highlights the point that not all offshorable jobs are routine and that not all non-offshorable jobs are non-routine. The correlation between the offshorability index and the RTI index in Table A4 is 0.3 at the individual level in our sample. Thus, based on Panels A-C in Table 4, it is not clear that workers in offshorable occupations are more likely to become unemployed and that workers in non-offshorable occupations are less likely to become unemployed.

Panel A of Table 5 displays estimates of the treatment effects for offshorable and non-offshorable workers. Column 2 displays the estimated treatment effects for workers in offshorable occupations. Although the estimated treatment effect is positive, it is far from statistically significant. Column 3 displays the estimated treatment effect for workers in non-offshorable occupations. Here, the estimated treatment effect is negative, but it is statistically insignificant. Thus, although the signs correspond with the idea of offshoring, the effects are not statistically significant.

Next, we separate firms with high and low productivity. First, we consider the workers in

ex ante low-productivity firms (Panel B). The workers in offshorable occupations experienced an 
increase of $4.8 \%$ in unemployment incidence (Column 2). This estimate is statistically significant with a t-value of 3.50 , and it is economically meaningful and corresponds to a $55.8 \%$ increase in unemployment incidence. Workers in non-offshorable occupations experience a $2 \%$ decrease in unemployment incidence. The estimated effect is statistically significant with a t-value of -2.28 and corresponds to a decrease of $12.7 \%$ in unemployment incidence. However, workers in ex ante high-productivity firms see no change in unemployment incidence (Panel C). This finding holds independent of whether the workers are in offshorable or non-offshorable occupations (Columns 2 and 3). Thus, this evidence suggests that offshoring is more likely to occur in less-productive firms.

These results provide new insights regarding cost-cutting and focusing efforts after buyouts. The media often cover layoffs that result from offshoring in the wake of buyouts. ${ }^{28}$ However, we are unaware of any direct or indirect empirical evidence that indicates that offshoring after buyouts occurs systematically. The results in Table 5 provide indirect evidence that offshoring in low-productivity firms occurs and points to groups of pre-existing workers that are most likely to be affected. The evidence of offshoring can be reconciled with the existing literature. Harris et al. (2005) suggest that productivity improvements and reductions in labor intensity after buyouts could represent outsourcing. Our results regarding offshoring provide evidence that supports this suggestion. Davis et al. (2014) provide evidence of shrinking pre-existing establishments and lowered unit labor costs after buyouts in the United States. Our results suggest that one contributing factor to this pattern could be offshoring.

\section{Tougher Bargaining with Labor Unions}

\subsection{Motivation}

The final explanation for layoffs after buyouts relates to tougher bargaining with labor unions. Buyouts increase leverage and align the incentives of managers and owners (Jensen, 1989; Axelson et al., 2013). Axelson et al. (2013) provide cross-country evidence for leverage associated with buyouts between 1986 and 2008. The average buyout in their sample raised $69 \%$ of the capital for

\footnotetext{
${ }^{28} \mathrm{~A}$ well-known example is Bain Capital, which was accused of offshoring American jobs to low-cost countries, such as China. This criticism spilled over to the former Bain Capital CEO, Mitt Romney, in his presidential campaign in 2012. (See, for example, the Reuters article "Buyouts-Controversial Sensata a textbook case for Bain Capital" published on July 26, 2012).
} 
the transaction through debt. This resulted in an average debt-to-EBITDA ratio of 5.6. Buyouts in the United States in the 1980s resulted in a fourfold increase in management ownership (Kaplan, 1989). In addition, Kaplan and Strömberg (2009) analyze a sample of buyouts in the United States between 1996 and 2004. In their sample, the management team obtained an average equity upside of $16 \%$.

Higher leverage and stronger incentives for management both contribute to improving the bargaining power of a firm with respect to labor unions. First, higher leverage works as a commitment device. Perotti and Spier (1993) show how firms can use leverage strategically to force concessions from workers. When leverage increases, the firm can credibly threaten to stop undertaking new investments unless the wage bill is reduced; otherwise, the firm goes bankrupt. Empirical evidence suggests that corporate leverage is related to union bargaining power. For example, Bronars and Deere (1991) show that firms under the threat of union action choose to maintain higher debt-equity ratios, and Rosett (1990) show that wealth concessions made by unions can explain approximately $3 \%$ of the shareholder gains in hostile takeovers over a six-year period. Moreover, Matsa (2010) document that higher union coverage affects capital structure, and Benmelech et al. (2012) provide empirical evidence that financial distress in airline companies is related to pension underfunding and wage concessions.

Second, stronger incentives for managers and an ownership change ca.n break implicit collusive agreements between managers and workers (Shleifer and Summers, 1988; Pagano and Volpin, 2005). Pagano and Volpin (2005) argue that managers sometimes align themselves with workers to fend off hostile takeovers. This strategy can help managers keep their jobs. Managers reward workers with higher pay and other benefits. In turn, workers protest and increase their voice in the media if hostile takeovers become imminent. Such collusive agreements are likely useful for managers if unions are aggressive and ready to fight takeovers because the workers have less to offer managers if they are not associated with aggressive labor unions. Cronqvist et al. (2009) provide evidence from Sweden that entrenched managers pay their workers more. This effect is stronger in industries where unions are more inclined to conflict. In addition, the collusion argument is supported by Rauh (2006), Kim and Ouimet (2014), and Atanassov and Kim (2009). ${ }^{29}$ Finally, Ippolito and

\footnotetext{
${ }^{29}$ Rauh (2006) find that employee stock ownership through defined contribution plans reduces the probability of a takeover. Kim and Ouimet (2014) documents that large-scale employee stock ownership plans can increase employee compensation. Atanassov and Kim (2009) show that top managers are less likely to be replaced as union power
} 
James (1992) present evidence that the buyouts in the United States in the 1980s were associated with pension terminations. Pensions can be seen as implicit promises of future payouts, which suggests that breaches of implicit contracts occurred, as hypothesized by Shleifer and Summers (1988).

Thus, tougher bargaining with labor unions could explain layoffs after buyouts. Consequently, we expect a positive treatment effect for workers affiliated with more aggressive unions. When unions are more aggressive, managers are more likely to avoid confrontation when strong incentives are absent, and they are more likely to collude with workers. In addition, we expect the treatment effect to be larger if the firm has low leverage in relation to its peers. For these firms, the change in bargaining power should be greater than that for those firms that already have high leverage.

\subsection{Results}

Swedish registry data do not contain information regarding union affiliation. Thus, we use the method of Cronqvist et al. (2009) and divide the workers based on the industries in which they worked. Lindberg (2006) document that there are six highly conflict-inclined unions in Sweden, including the Swedish Electricians Union, the Swedish Painters' Union, the Swedish Builders Workers' Union, the Swedish Transportation Workers' Union, the Swedish Dock Workers' Union, and the Syndicalists. As demonstrated by Cronqvist et al. (2009), we code workers in the construction industry (SNI code 45) and the transportation industry (SNI code 60-63) as members of aggressive labor unions. Blue-collar workers in the construction industry tend to belong to the Swedish Electricians Union, the Swedish Painters' Union, or the Swedish Builders Workers' Union. Blue-collar workers in the transportation industry tend to belong to the Swedish Transportation Workers' Union, the Swedish Dock Workers' Union or the Syndicalists.

Panel A in Table 6 displays the estimated treatment effect for workers in industries with aggressive unions (Column 2) and for those who work in industries with non-aggressive unions (Column 3). For workers in industries with aggressive unions, the point estimate is positive, but it is imprecisely estimated with a t-value of 1.64. Although this estimate is statistically insignificant, it is economically meaningful. The point estimate of 1.2 percentage points corresponds to a $14.3 \%$ increase

increases in countries with low investor protection. These findings suggest that strong union laws encourage workermanagement alliances. Furthermore, Atanassov and Kim (2009) document that strong union laws are less effective for preventing layoffs when financial leverage is high. 
in the unemployment incidence. The point estimate for workers in industries with non-aggressive unions is small and statistically insignificant.

However, not all firms experience the same increase in leverage or the same change in bargaining power following a buyout. The estimated effects should be greater if the ex ante leverage of the firm is low. Consequently, we divide up the workers based on the ex ante leverage of the firms in which they worked. We define a firm as an ex ante low-leverage firm if it has a leverage ratio that was below the two-digit industry median the year before the buyout announcement.

Panel B in Table 6 presents the estimated treatment effects for workers in firms with ex ante low leverage. On average, the estimated effect is economically and statistically insignificant (Column 1). For workers in industries with aggressive labor unions, the point estimate increases in size and significance (Column 2). We estimate a 1.8 percentage point increase in unemployment incidence that is statistically significant with a t-value of 2.11 and that corresponds to a $23.1 \%$ increase in unemployment incidence. The estimated treatment effect for workers in firms with low ex ante leverage in non-aggressive industries is nearly zero. Panel $\mathrm{C}$ presents the estimated treatment effects for workers in firms with high ex ante leverage. The estimated treatment effects for these workers is economically and statistically insignificant overall (Column 1). The estimated effect is insignificant for workers in industries with aggressive labor unions and for workers in non-aggressive industries (Columns 2 and 3). These results strengthen the evidence supporting the notion that tougher bargaining with labor unions can explain layoffs after buyouts.

Next, we separate blue-collar and white-collar workers. Blue-collar workers and white-collar workers join different unions, and blue-collar worker unions are more likely to be involved in conflict (Lindberg, 2006). Thus, we expect the treatment effect to be driven by blue-collar workers and not by white-collar workers.

Panel D in Table 6 presents the estimated treatment effects for blue-collar and white-collar workers. We restrict our attention to workers in firms with low leverage and in industries with aggressive unions. Column 1 replicates Column 2 of Panel B and shows the estimated treatment effect for workers in firms with low leverage and in industries with aggressive unions. Columns 2 and 3 display the estimated effects for blue-collar and white-collar workers, respectively. As expected, blue-collar workers drive the effect for workers at the ex ante low leverage firms. Bluecollar workers experience a $23.1 \%$ increase in unemployment incidence. The treatment effect for 
white-collar workers is statistically insignificant.

In summary, the evidence in Table 6 suggests that buyouts help firms bargain with labor unions. This interpretation is consistent with the literature that documents a robust link between the financial policy of the firm and labor outcomes. ${ }^{30}$ In addition, our results can help shed new light on the debate between value capture and value creation in buyouts. This debate goes back to early studies on buyouts. Jensen (1989) argue that private equity ownership is a superior organizational form that creates value. This view is often contrasted with that of Shleifer and Summers (1988), who argue that buyouts capture value from workers and other stakeholders. Existing empirical evidence shows that productivity improvements follow buyouts. ${ }^{31}$ Furthermore, several studies show few negative effects on long-run investments (Lerner et al., 2011), little evidence of tax gains (Jenkinson and Stucke, 2011), and little evidence of decreases in firm-level employment. ${ }^{32}$ Thus, it is easy to conclude that private equity firms create value. We do not deny that this is the best assessment of the average effects of buyouts. However, our results suggest that value creation does not rule out value capture. The results presented in Table 6 are consistent with value capture from some workers.

\section{Additional Analysis and Discussion}

\subsection{Firm-level Outcomes}

The previous three sections focused on providing worker-level evidence in support of automation, offshoring, and tougher bargaining with labor unions as explanations for layoffs after buyouts.

However, our results also show that buyouts of ex ante highly productive firms are not associated with an increased unemployment incidence. In this section, by analyzing firm-level outcomes, we further investigate how the effect of buyouts varies with the ex ante productivity of the targeted firm. A firm-level analysis can also help determine how worker-level treatment effects are related to firm-level treatment effects. In addition, this analysis can help us understand whether Swedish buyouts are comparable to buyouts in other countries. Thus, this subsection complements the

\footnotetext{
${ }^{30}$ See, for example, Bronars and Deere (1991), Rosett (1990), Matsa (2010), or Benmelech et al. (2012).

${ }^{31}$ See, for example, Kaplan (1989), Lichtenberg and Siegel (1990), Amess (2002), Amess (2003), Harris et al. (2005) and Davis et al. (2014).

${ }^{32}$ See, for example, Kaplan (1989), Muscarella and Vetsuypens (1990), Lichtenberg and Siegel (1990), Bergström et al. (2007), Boucly et al. (2011), Amess and Wright (2012), and Davis et al. (2014).
} 
discussion regarding the Swedish private equity market that we provide in Appendix A.

We estimate several versions of the following model:

$$
Y_{f g t}=\alpha+\delta P O S T_{t}+\gamma L B O_{g}+\beta\left(P O S T_{t} \times L B O_{g}\right)+\pi F_{f}+\lambda_{r}+\epsilon_{f g t},
$$

where $Y_{f g t}$ is the outcome for firm $\mathrm{f}$ in group g at time t. The $P O S T_{t}$ dummy is assigned a value of one for the year of the buyout announcement and all years after. The $L B O_{g}$ dummy is assigned a value of one for the treated firms and a value of zero for the matched firms. The coefficient $\beta$ captures the firm-level treatment effect, which measures the average change of the outcome variable for the treated firms in the post-buyout period. We include firm controls $F_{f}$ to increase the efficiency and to control for common industry and region effects. The term $\lambda_{r}$ represents the yearly fixed effects. $^{33}$

The firm-level outcomes we analyze include the firm size, number of establishments, sales, fixed assets, value added per employee, and return on assets. ${ }^{34}$ In addition, because we observe flows of workers in and out of firms, we add the number of workers separated from the firm and the number of workers hired by the firm. We take the log of all variables except for return on assets to mitigate the impacts of outliers. To avoid taking the log of zero, we add one to the number of separations and to the number of hires. To better link the worker-level effects to the firm-level effects, we weigh all of the firm-level models with the size of the firm the year before the buyout announcement $(t=0)$.

The identifying assumption for the $\beta$ coefficient to capture a causal treatment effect is that the treated and control groups have parallel trends in the outcome variable in the absence of treatment. Similar to the worker-level analysis, we assess the plausibility of the assumption by comparing trends in the outcome variables before treatment. Similar trends indicate that economic shocks affected the treated and control groups in similar ways before the buyout. Figure 2 displays the trends for the firm-level outcomes that we focus on. All outcomes show parallel trends prior to buyout announcements.

In sharp contrast with our worker-level analysis, our firm-level analysis could suffer from attri-

\footnotetext{
${ }^{33}$ The subindex $r$ represents the actual year $(r=1994,1995, \ldots, 2011)$, in contrast with the subindex $t$, which represents the normalized time period $(t=-4,-3 \ldots, 4)$.

${ }^{34}$ These outcomes were also analyzed in previous studies, e.g., Bergström et al. (2007), Boucly et al. (2011), Amess and Wright (2012), and Davis et al. (2014).
} 
tion bias. As discussed by Davis et al. (2014), buyouts can be associated with complex restructuring, such as internal organization, acquisitions, and divestitures. This can make it difficult to track target firms over time. To reduce any attrition bias, we restrict our attention to three years before the announcement of the buyout and two years after. ${ }^{35}$ Despite the restriction to the three post years, we observe attrition. Figure A2 in the Appendix shows that the treated firms left the sample pool sooner than the control firms. The higher attrition rate among the treated firms makes us less confident that the firm-level treatment effects can be interpreted as causal. For example, a higher death rate among the treated firms implies that the treated survivors are of higher quality than the control survivors, which introduces an upward bias for the estimated treatment effect on, for instance, firm size.

Panel A in Table 7 presents the firm-level treatment effects based on the model specified in Equation 2. The estimated treatment effect in Columns 1 to 8 show no large change in net employment at the firm level. This finding corresponds with previous observations in Sweden by Bergström et al. (2007), in the United Kingdom by Amess and Wright (2012), and in the United States by Davis et al. (2014), but it differs from the positive firm size effect that was observed for French buyouts by Boucly et al. (2011). The signs of our point estimates on hirings and separations correspond with the findings of Davis et al. (2014) of greater job creation and job destruction, but our estimates are not statistically significant. In addition, similar to Davis et al. (2014), we find evidence of productivity improvements after buyouts. The value added per employee increases by an average of $4.4 \%$ in our sample. ${ }^{36}$

As discussed in the worker-level analysis, the motivation for buyouts could differ depending on the ex ante productivity of the targeted firms. To examine this issue, we separate our sample of buyouts into two groups based on ex ante productivity. A firm is defined as ex ante high/low productivity if its value added per employee at $t=0$ is above/below the median of the two-digit industry in which it operates. These groups are the same as those used in the worker-level analysis.

Panel B presents firm-level results for buyouts where the target firms had low ex ante produc-

\footnotetext{
${ }^{35}$ The accounting data begin in 1998. Consequently, the models for sales, fixed assets, value added per employee and ROA are based on unbalanced panels, and the buyouts announced before 2001 have incomplete pre-information. To mitigate the attrition bias further, we also use FAD codes instead of firm legal identifiers when follow firms over time. See the description in Table A1.

${ }^{36}$ The exact percentage change in a semi-log model for a dummy is $100 \times[\exp (\beta)-1]$. However, the correction is only crucial for large percentage changes.
} 
tivity. Our worker-level results above suggest that low-productivity firms are restructured through automation and offshoring. For target firms with low productivity, we estimate that the average firm size and the average number of establishments remain unchanged after a buyout. In addition, there is no treatment effect for separations and hirings. This pattern is consistent with the opposing effects on the unemployment incidence that we estimated above for routine/offshorable workers and non-routine/non-offshorable workers. The worker-level effects are translated into productivity and profitability gains at the firm level. The value added per employee increases by $10.7 \%$ (an increase of $0.102 \log$ points), and the return on assets increases by $4.7 \%$.

Panel C presents the results for buyouts where the target firm had high ex ante productivity. For these firms, we estimate that the firm size increases by an average of $12.6 \%$ (an increase of 0.119 $\log$ points) after a buyout. This employment effect is consistent with the employment effect of $12 \%$ that was observed for growth buyouts in France (Boucly et al., 2011). Moreover, we estimate that the number of establishments increases by $14.5 \%$ (an increase of 0.135 log points) and the number of hirings increases by $22.1 \%$ (an increase of $0.200 \log$ points) after the buyout. Firm productivity and profitability appear to remain unchanged.

Taken together, Panels B and C suggest that two types of buyouts take place in our sample. Firms with low productivity relative to their peers are targets of buyouts that focus more on restructuring (as documented by Davis et al. (2014) for the United States), whereas firms with high ex ante productivity relative to their peers are targets of buyouts that focus more on growth (as documented in France by Boucly et al. (2011)).

Two remarks must be made. First, we estimate no effects on fixed assets in any of our samples. The accounting item "Fixed Assets" is the best measure we have for investments after buyouts. The notion that automation can explain layoffs would suggest that investments should accelerate after a buyout. However, two countervailing forces can play a role in this outcome. First, fixed assets can expand if new investments occur following a buyout. Second, private equity firms often sell buildings and rent them back to finance new investments. This process reduces a firm's fixed assets. In unreported regressions, we observe that the accounting item "Intangible Assets" increase by more than $500 \%$ in ex ante low-productivity target firms (an increase of 1.806 log points with a t-value of 1.85). The accounting item "Intangible Assets" includes corporate intellectual property, including software that can be used for automation. Thus, the increase in intangible assets in ex 
ante low-productivity target firms is consistent with the indirect evidence of automation presented in Section 3.

Second, the firm-level analysis underscores that studying worker-level outcomes is important for understanding the consequences of buyouts for pre-existing workers. Based on the firm size estimate in Table 7 in Panels A, B and C, it is easy to conclude that no negative effect on labor occurred as a result of buyouts. This conclusion overlooks the fact that buyouts can affect workers differently.

\subsection{Discussion}

We believe that our results present compelling evidence that layoffs after buyouts can be explained using the same mechanisms that have been used to explain the job polarization process. Overall, two key remarks are important regarding the interpretation of our results.

First, we can compare buyouts to other events that affect workers. This exercise can provide us with a better picture of the economic significance of the estimated effects. One example of a shock that affected workers during our sample period is the global financial crisis, which led to a reduction in the Swedish gross domestic product of 5.7\% between 2007 and 2009. The unemployment rate increased by approximately three percentage points (50.8\%) between 2007 and 2009. A back-of-theenvelope calculation suggests that the financial crisis was slightly worse for workers in comparison with a buyout. For routine workers in low-productivity firms, the financial crisis and buyouts produced similar effects on moves to unemployment. For workers in offshorable occupations in low-productivity firms and for blue-collar workers in industries with aggressive labor unions, the financial crisis was worse. ${ }^{37}$

Second, the explanations for layoffs we advance have policy implications. Policy advice regarding how to mitigate the effects of the job polarization process on workers can be interpreted as policy advice on how to mitigate the effects of layoffs after buyouts on workers. For example, Autor (2010) mentions encouraging training programs to boost the skill levels, earnings power, and mobility of

\footnotetext{
${ }^{37}$ The unemployment incidence for routine workers employed in low-productivity firms in 2007 increased by 6.7 percentage points (73\%) between 2007 and 2009. In comparison, the estimated treatment effect from buyouts was 6.6 percentage points $(63 \%)$. For workers in offshorable occupations in low-productivity firms, the unemployment incidence increased by 7.9 percentage points (102\%) between 2007 and 2009. In comparison, we estimate a treatment effect of buyouts of 4.8 percentage points (56\%). The unemployment incidence for blue-collar workers in low-leverage firms in industries with conflict-inclined unions increased by 2.8 percentage points (44\%) between 2007 and 2009 . For comparison, we estimate an increase of 1.8 percentage points $(23 \%)$.
} 
workers as one policy response to job polarization that is worthy of discussion. We conjecture that such programs could help workers who are laid off after a buyout as well.

\section{Conclusions}

What can explain layoffs after private equity buyouts? In this paper, we use detailed registry data from Sweden to answer this question. We argue that layoffs in private equity buyouts can be understood through the lens of the job polarization process. Job polarization refers to the pattern of increasing employment in most developed countries in low- and high-skilled jobs but decreasing employment in medium-skilled jobs. At least three explanations have been considered for this "hollowing out of the middle class", including the automation of routine jobs due to technological progress, the globalization of product and labor markets, and the weakening of labor unions over time. We argue that these same explanations could be important for understanding layoffs after private equity buyouts. Private equity firms reduce agency costs, which triggers investments that automate routine jobs, offshoring, and tougher bargaining with labor unions.

Using detailed worker-level data, we present evidence in support of these three explanations. Workers in less-productive firms in routine or offshorable job tasks are more likely to lose their jobs after a buyout. The opposite holds for workers doing non-routine or non-offshorable tasks. Moreover, entrenched workers - that is, blue-collar workers in industries with aggressive labor unions and firms with low leverage - are more likely to lose their jobs. Together, these results suggest that private equity firms could accelerate the job polarization process. 


\section{References}

Abadie, A. and G. W. Imbens (2012). Matching on the estimated propensity score. Mimeo.

Acemoglu, D. and D. Autor (2011). Skills, tasks, and technologies: Implications for employment and earnings. In D. Card and O. Ashenfelter (Eds.), Handbook of Labor Economics, Volume 4, Chapter 12, pp. 1043-1171. Elsevier.

Acharya, V. V., O. F. Gottschalg, M. Hahn, and C. Kehoe (2013). Corporate governance and value creation: Evidence from private equity. Review of Financial Studies 26, 368-402.

Adermon, A. and M. Gustavsson (2014). Job polarization and task-based technological change: Evidence from Sweden 1975-2005. Forthcoming in The Scandinavian Journal of Economics.

Agrawal, A. and P. Tambe (2014). Private equity, technological investment, and labor outcomes. Available at SSRN: http://ssrn.com/abstract $=2286802$.

Amess, K. (2002). Management buyouts and firm-level productivity: evidence from a panel of UK manufacturing firms. Scottish Journal of Political Economy 49, 304-16.

Amess, K. (2003). The effect of management buyouts on firm-level technical efficiency: evidence from a panel of UK machinery and equipment manufacturers. Journal of Industrial Economics 51, $35-44$.

Amess, K., S. Brown, and S. Thompson (2007). Management buyouts, supervision and employee discretion. Scottish Journal of Political Economy 54, 447-74.

Amess, K. and M. Wright (2012). Leveraged buyouts, private equity and jobs. Small Business Economics 38, 419-430.

Andersson, J. and G. Arvidson (2006). Företages och arbetställenas dynamik (FAD). Available from Statistics Sweden.

Angrist, J. D. and J.-S. Pischke (2009). Mostly harmless econometrics: An empiricist's companion. Princeton University Press. 
Atanassov, J. and E. H. Kim (2009). Labor and corporate governance: International evidence from restructuring decisions. Journal of Finance 64, 341-374.

Autor, D. (2010). The polarization of job opportunities in the U.S. labor market: Implications for employment and earnings. Center for American Progress and The Hamilton Project.

Autor, D. H. and D. Dorn (2013). The growth of low-skill service jobs and the polarization of the US labor market. American Economic Review 103, 1553-1597.

Autor, D. H., L. F. Katz, and M. S. Kearney (2006). The polarization of the US labor market. American Economic Review 96, 189-194.

Autor, D. H., L. F. Katz, and M. S. Kearney (2008). Trends in US wage inequality: Revising the revisionists. Review of Economics and Statistics 80, 300-323.

Autor, D. H., F. Levy, and R. J. Murnane (2003). The skill content of recent technological change: An empirican exploration. Quarterly Journal of Economics 118, 1297-1333.

Axelson, U., T. Jenkinson, P. Strömberg, and M. S. Weisbach (2013). Borrow cheap, buy high? The determinants of leverage and pricing in buyouts. Journal of Finance 68, 2223-2267.

Benmelech, E., N. K. Bergman, and R. J. Enriquez (2012). Negotiating with labor under financial distress. Review of Corporate Finance Studies 1, 28-67.

Bergström, C., M. Grubb, and S. Jonsson (2007). The operating impact of buyouts in Sweden: A study of value creation. Journal of Private Equity 11, 22-39.

Blinder, A. S. (2006). Offshoring: The next industrial revolution? Foreign Affairs 85, 113-128.

Blinder, A. S. and A. B. Krueger (2013). Alternative measures of offshorability: A survey approach. Journal of Labor Economics 31, S97-S128.

Bloom, N., R. Sadun, and J. van Reenen (2009). Do private equity-owned firms have better management practices? In The Globalization of Alternative Investments Working Papers Volume 2: The Global Economic Impact of Private Equity Report 2009, pp. 25-43. Geneva: World Economic Forum. 
Boucly, Q., D. Sraer, and D. Thesmar (2011). Growth LBOs. Journal of Financial Economics 102, $432-453$.

Bronars, S. G. and D. R. Deere (1991). The threat of unionization, the use of debt, and the preservation of shareholder wealth. Quarterly Journal of Economics 106, 231-254.

Cronqvist, H., F. Heyman, M. Nilsson, H. Svaleryd, and J. Vlachos (2009). Do entrenched managers pay their workers more? Journal of Finance 64, 309-339.

Davis, S. J., J. C. Haltiwanger, K. Handley, R. S. Jarmin, J. Lerner, and J. Miranda (2014). Private equity, jobs, and productivity. American Economic Review 104, 3956-90.

Di Tella, R., R. MacCullock, and A. Oswald (2001). Preferences over inflation and unemployment: Evidence from surveys of happieness. American Economic Review 91, 335-341.

Edgerton, J. (2012). Agency problems in public firms: Evidence from corporate jets in leveraged buyouts. Journal of Finance 67, 2187-2213.

Farber, H. S. (2005). What do we know about job loss in the United States? Evidence from the displaced workers survey 1984-2004. Federal Reserve Bank of Chicago Economic Perspectives 29, $13-28$.

FSA (2008). Private equity: A discussion of risk and regulatory engagement. Financial Services Authority Discussion Paper DP06/6.

Goos, M., A. Manning, and A. Salomons (2014). Explaining job polarization: Routine-biased technological change and offshoring. American Economic Review 8, 2509-2526.

Graham, J. R., H. Kim, S. Li, and J. Qiu (2013). Human capital loss in corporate bankruptcy. Available at SSRN: http://ssrn.com/abstract $=2276753$.

Gruber, J. (1997). The consumption smoothing benefits of unemployment insurance. American Economic Review 87, 192-205.

Harris, R., D. S. Siegel, and M. Wright (2005). Assessing the impact of management buyouts on economic efficiency: Plant level evidence from the United Kingdom. Review of Economics and Statistics 87, 148-153. 
Heckman, J., H. Ichimura, and P. Todd (1997). Matching as an econometric evaluation estimator: evidence from evaluating a job training program. Review of Economic Studies 64, 605-54.

Heckman, J. J., H. Ichimura, and P. Todd (1998). Matching as an econometric evaluation estimator. Review of Economic Studies 65, 261-294.

Imbens, G. W. and J. M. Wooldridge (2009). Recent developments in the econometrics of program evaluation. Journal of Economic Literature 47, 5-86.

Ippolito, R. and W. James (1992). LBOs, reversions and implicit contracts. Journal of Finance 47, $139-167$.

ITUC (2007). Where the house always wins: Private equity, hedge funds and the new casino capitalism. International Trade Union Confederation.

Jacobson, L. S., R. J. LaLonde, and D. G. Sullivan (1993). Earnings losses of displaced workers. American Economic Review 83, 685-709.

Jenkinson, T. and R. Stucke (2011). Who benefits from the leverage in LBOs? Available at SSRN: http://ssrn.com/abstract $=1777266$.

Jensen, M. C. (1986). Agency costs of free cash flow, corporate finance and takeovers. American Economic Review 76, 323-329.

Jensen, M. C. (1989). The eclipse of the public corporation. Harvard Business Review 67, 61-74.

Kaplan, S. N. (1989). The effects of management buyouts on operating performance and value. Journal of Financial Economics 24, 217-254.

Kaplan, S. N. and P. Strömberg (2009). Leveraged buyouts and private equity. Journal of Economic Perspectives 23, 121-146.

Katz, L. F. and B. D. Mayer (1990). The impact of the potential duration of unemployment benefits on the duration of unemployment. Journal of Public Economics 41, 45-72.

Kim, E. H. and P. Ouimet (2014). Broad-based employee stock ownership: Motives and outcomes. Journal of Finance 69, 1273-1319. 
Larsson, M. (2012). Fackling anslutning år 2012. Report by LOs Arbetslivsenhet.

Lazear, E. P. and K. L. Shaw (2009). The Structure of Wages: An international comparison. University of Chicago Press.

Lerner, J., F. Hardymon, and A. Leamon (2008). Venture Capital and Private Equity: A Casebook (4th ed.). Jogn Wiley \& Sons.

Lerner, J., M. Sorensen, and P. Strömberg (2011). Private equity and long-run investment: The case of innovation. Journal of Finance 66, 445-477.

Lichtenberg, F. and D. S. Siegel (1990). The effects of leveraged buyouts on productivity and related aspects of firm behavior. Journal of Financial Economics 27, 165-194.

Lindberg, H. (2006). Konflikt, konkurrens och korporativa karteller - Nya konfliktmönster och konfliktdimensioner på svensk arbetsmarknad 1993-2005. Stockkholm, Sweden.: RATIO.

Lopez de Silanes, F., L. Phalippou, and O. Gottschalg (2014). Giants at the gate: Investment returns and diseconomies of scale in private equity. Forthcoming in Journal of Financial and Quantitative Analysis.

Matsa, D. A. (2010). Capital structure as a strategic variable: Evidence from collective bargaining. Journal of Finance 65, 1197-1232.

Moulton, B. R. (1986). Random group effects and the precision of regression estimates. Journal of Econometrics 32, 385-397.

Muscarella, C. J. and M. R. Vetsuypens (1990). Efficiency and organizational structure: A study of reverse LBOs. Journal of Finance 45, 1389-1413.

Nilsson Hakkala, K., F. Heyman, and F. Sjöholm (2014). Multinational firms, acquisitions and job tasks. European Economic Review 66, 248-265.

OECD (2004). OECD employment outlook 2004. OECD, Paris.

Pagano, M. and P. Volpin (2005). Managers, workers, and corporate control. Journal of Finance 60, $841-868$. 
Perotti, E. C. and K. E. Spier (1993). Capital structure as a bargaining tool: The role of leverage in contract renegotiation. American Economic Review 83, 1131-1141.

PSE (2007). Hedge funds and private equity: A critical analysis. Report of the PSE Group in European Parliament.

Rauh, J. D. (2006). Own company stock in defined contribution pension plans: A takeover defence? Journal of Financial Economics 81, 379-410.

Rosenbaum, P. R. and D. B. Rubin (1983). The central role of the propensity score in observational studies for causal effects. Biometrika 70, 41-55.

Rosett, J. G. (1990). Do union wealth concessions explain takeover premiums? The evidence on contract wages. Journal of Financial Economics 27, 263-282.

Shleifer, A. and L. H. Summers (1988). Breach of trust in hostile takeovers. In A. J. Auerbach (Ed.), Corporate Takeovers: Causes and Consequences, Chapter 2, pp. 33-68. University of Chicago Press.

Smith, J. A. and P. Todd (2005). Does matching overcome lalonde's critique of nonexperimental estimators? Journal of Econometrics 125, 305-353.

Strömberg, P. (2008). The new demography of private equity. In A. Gurung and J. Lerner (Eds.), The Globalization of Alternative Investments Working Papers Volume 1: The Global Economic Impact of Private Equity Report 2008, pp. 1-26. Geneva: World Economic Forum.

Tåg, J. (2012). The real effects of private equity buyouts. In The Oxford Handbook of Private Equity, Chapter 10, pp. 271-300. Oxford University Press.

Tambe, P. and L. Hitt (2012). Now IT's personal: Offshoring and the shifting skill composition of the US information technology workforce. Management Science 58, 678-697.

Tjärnback, E. (2009). Owned by private equity. Report by Unionen's research and policy department.

Wright, M., S. Thompson, and K. Robbie (1992). Venture capital and management-led leveraged buyouts: A European perspective. Journal of Business Venturing 7, 47-71. 


\section{Table 1: Descriptive Statistics on Buyouts}

This table reports the descriptive statistics for the buyouts in the final sample (Column 1). In addition, descriptive statistics are reported based on employment weighting in the final sample (Column 2) and based on the buyouts in Capital IQ that were matched to firm identifiers (Column 3). The final three columns report descriptive statistics for the buyouts that were undertaken in the United States (Column 4), in the United Kingdom (Column 5), and in France (Column 6) based on data from Capital IQ. Panel A displays the buyouts per transaction type, Panel B displays the average and standard deviations of the transaction values (in millions of U.S. dollars at a nominal rate), and Panel $\mathrm{C}$ displays the distribution of buyouts in the samples over time.

\begin{tabular}{|c|c|c|c|c|c|c|}
\hline Sample & $\begin{array}{r}\text { Final } \\
1\end{array}$ & $\begin{array}{r}\text { Weighted } \\
2\end{array}$ & $\begin{array}{r}\text { Sweden } \\
3\end{array}$ & $\begin{array}{r}\mathrm{US} \\
4\end{array}$ & $\begin{array}{r}\text { UK } \\
5\end{array}$ & $\begin{array}{r}\text { France } \\
6\end{array}$ \\
\hline \multicolumn{7}{|l|}{ Panel A: Transaction Types } \\
\hline $\begin{array}{l}\text { Going Private } \\
\text { Corporate Divestiture } \\
\text { Bankruptcy } \\
\text { Management Buyout } \\
\text { Family Succession } \\
\text { Cross Border } \\
\text { Platform }\end{array}$ & $\begin{array}{r}2.56 \% \\
32.10 \% \\
1.14 \% \\
20.45 \% \\
3.98 \% \\
30.11 \% \\
3.69 \%\end{array}$ & $\begin{array}{r}8.23 \% \\
32.46 \% \\
5.94 \% \\
13.67 \% \\
1.97 \% \\
43.76 \% \\
8.86 \%\end{array}$ & $\begin{array}{r}3.35 \% \\
35.98 \% \\
1.05 \% \\
22.38 \% \\
3.35 \% \\
30.54 \% \\
3.35 \%\end{array}$ & $\begin{array}{r}5.25 \% \\
29.37 \% \\
3.41 \% \\
23.87 \% \\
3.77 \% \\
5.65 \% \\
8.84 \%\end{array}$ & $\begin{array}{r}5.03 \% \\
30.97 \% \\
3.72 \% \\
59.87 \% \\
3.85 \% \\
11.12 \% \\
2.43 \%\end{array}$ & $\begin{array}{r}1.25 \% \\
17.02 \% \\
2.55 \% \\
35.08 \% \\
7.37 \% \\
19.62 \% \\
2.34 \%\end{array}$ \\
\hline \multicolumn{7}{|l|}{ Panel B: Transaction Values } \\
\hline $\begin{array}{l}\text { Average (million USD) } \\
\text { Standard Deviation (million USD) }\end{array}$ & $\begin{array}{l}193.98 \\
403.68\end{array}$ & $\begin{array}{l}- \\
-\end{array}$ & $\begin{array}{l}190.27 \\
542.71\end{array}$ & $\begin{array}{r}367.78 \\
1871.56\end{array}$ & $\begin{array}{l}168.40 \\
683.51\end{array}$ & $\begin{array}{l}220.02 \\
588.59\end{array}$ \\
\hline \multicolumn{7}{|l|}{ Panel C: Transactions } \\
\hline 1999 & 20 & - & 27 & 701 & 205 & 112 \\
\hline 2000 & 20 & - & 19 & 564 & 242 & 106 \\
\hline 2001 & 30 & - & 39 & 543 & 381 & 121 \\
\hline 2002 & 24 & - & 31 & 702 & 316 & 133 \\
\hline 2003 & 24 & - & 33 & 757 & 404 & 170 \\
\hline 2004 & 28 & - & 44 & 918 & 374 & 230 \\
\hline 2005 & 37 & - & 51 & 975 & 408 & 299 \\
\hline 2006 & 56 & - & 75 & 1233 & 615 & 321 \\
\hline 2007 & 61 & - & 86 & 1432 & 672 & 375 \\
\hline 2008 & 51 & - & 73 & 1137 & 616 & 371 \\
\hline Total & 351 & - & 478 & 8962 & 4278 & 2238 \\
\hline
\end{tabular}


Table 2: Descriptive Statistics of Workers and Firms

This table reports the descriptive statistics for treated and control firms and their workers (Columns 1 and 2 ). In addition, this table contains the descriptive statistics for a random sample of firms in the economy and their workers (Column 3). We constructed the random sample by randomly drawing 10 firms per year for each buyout that was announced that year. The descriptive statistics refer to the year before the buyout announcement $(t=0)$. Columns 4 and 5 report the differences in means. We normalized the t-test for the worker-level variables to account for the larger sample size (Imbens and Wooldridge, 2009). Variable descriptions are available in Table A1. In addition, MSEK refers to millions of 2005 SEK, and TSEK refers to thousands of 2005 SEK (the USD/SEK exchange rate on June 30, 2005 was 7.6). We denote statistical significance at the $1 \%$ level by $* * *$.

\begin{tabular}{|c|c|c|c|c|c|}
\hline & \multicolumn{3}{|c|}{ Sample } & \multicolumn{2}{|c|}{ Difference } \\
\hline & \multirow{2}{*}{$\begin{array}{r}\text { Treated } \\
1\end{array}$} & \multirow{2}{*}{$\begin{array}{r}\text { Control } \\
2\end{array}$} & \multirow{2}{*}{$\begin{array}{r}\text { Random } \\
3\end{array}$} & \multirow{2}{*}{$\begin{array}{r}\text { Col. 1-2 } \\
4\end{array}$} & \multirow{2}{*}{$\begin{array}{r}\text { Col. 1-3 } \\
5\end{array}$} \\
\hline & & & & & \\
\hline \multicolumn{6}{|l|}{ Panel A: Worker Characteristics } \\
\hline \multirow[t]{2}{*}{ Age } & 39.6 & 39.8 & 40.0 & -0.2 & -0.5 \\
\hline & $(11.2)$ & $(11.3)$ & $(12.7)$ & & \\
\hline \multirow[t]{2}{*}{ Labor Income (TSEK) } & 256.1 & 258.5 & 242.8 & -2.3 & $13.3^{* * *}$ \\
\hline & $(172.4)$ & $(170.1)$ & $(160.2)$ & & \\
\hline \multirow{2}{*}{ Female $(\%)$} & 42.2 & 42.1 & 35.7 & 0.1 & 6.4 \\
\hline & $(49.4)$ & $(0.494)$ & $(47.9)$ & & \\
\hline \multirow[t]{2}{*}{ Share skilled (\%) } & 19.6 & 23.4 & 15.1 & -3.79 & 4.5 \\
\hline & $(39.7)$ & $(42.3)$ & $(35.8)$ & & \\
\hline \multirow[t]{2}{*}{ Tenure (years) } & 3.5 & 3.6 & 4.1 & -0.05 & -0.6 \\
\hline & $(4.2)$ & $(4.3)$ & $(4.6)$ & & \\
\hline Workers & 88879 & 83474 & 105286 & & \\
\hline \multicolumn{6}{|l|}{ Panel B: Firm Characteristics } \\
\hline \multirow[t]{2}{*}{ Size } & 126.0 & 118.7 & 13.8 & 7.2 & $112.2^{* * *}$ \\
\hline & $(308.4)$ & $(292.2)$ & $(110.7)$ & & \\
\hline \multirow{2}{*}{ Size Growth (\%) } & 38.3 & 42.3 & 33.0 & -3.9 & $5.4^{*}$ \\
\hline & $(77.5)$ & $(76.7)$ & $(77.5)$ & & \\
\hline \multirow[t]{2}{*}{ Age } & 7.3 & 7.3 & 6.6 & 0.0 & $0.5^{* * *}$ \\
\hline & $(6.7)$ & $(6.7)$ & $(6.1)$ & & \\
\hline \multirow[t]{2}{*}{ Fixed Assets (MSEK) } & 39.7 & 37.5 & 7.1 & 0.2 & $32.6^{* * *}$ \\
\hline & $(210.3)$ & $(258.0)$ & $(107.5)$ & & \\
\hline \multirow[t]{2}{*}{ Sales (MSEK) } & 221.7 & 215.4 & 25.6 & 2.71 & $196.0^{* * *}$ \\
\hline & $(616.6)$ & $(804.0)$ & $(301.7)$ & & \\
\hline \multirow[t]{2}{*}{ Value Added per Employee (TSEK) } & 681.3 & 619.9 & 458.7 & 61.45 & $222.7^{* * *}$ \\
\hline & $(1221.2)$ & $(1462.3)$ & $(1156.2)$ & & \\
\hline \multirow[t]{2}{*}{ Debt to Assets (\%) } & 11.4 & 9.9 & 17.2 & 1.50 & $-5.7 * * *$ \\
\hline & $(20.8)$ & $(16.5)$ & $(31.0)$ & & \\
\hline \multirow[t]{2}{*}{ Return on Assets (\%) } & 8.7 & 9.7 & 10.5 & -0.90 & -1.8 \\
\hline & $(47.5)$ & $(42.7)$ & $(34.8)$ & & \\
\hline Firms & 760 & 760 & 7600 & & \\
\hline
\end{tabular}


Table 3: Average Unemployment Incidence

This table reports the coefficient estimates and their t-values (in parentheses) from regressions that explain an individual's unemployment incidence. We cluster the standard errors at the firm-municipality level. Unemployment incidence is a dummy given a value of one for workers with at least one day of unemployment during a given year. The POST dummy is assigned a value of one the year of the buyout announcement and $(t=1)$ all years after the buyout announcement. The $L B O$ dummy is assigned a value of one for workers that are part of a buyout and a value of zero for workers in the control group. The regressions cover nine years, including four pre-periods, four post-periods, and the year of the buyout announcement. The individual controls are age, age squared, gender, annual labor income at $t=0$, a skill dummy taking the value of one for workers with at least two years of post-secondary education, tenure at $t=0$, and five dummies representing whether a worker has at least one day of unemployment at time $t=0, t=-1, t=-2, t=-3$, and $t=-4$. The firm controls include the size at $t=0$, size squared $t=0$, size growth from $t=-1$ to $t=0$, firm age at $t=0$, and firm age squared at $t=0$. We base the industry fixed effects on the Statistics Sweden SNI2002 industry classification at the two-digit level (45 dummies). In addition, we base the county fixed effects on the location of the establishment (20 dummies). Variable descriptions are available in Table A1. Average unemployment incidence refers to the average unemployment incidence for treated workers before $t=1$. The percentage change is the coefficient on $P O S T \times L B O$ divided by the average unemployment incidence. We denote statistical significance at the $1 \%$ level by $* * *$.

\begin{tabular}{|c|c|c|c|}
\hline Dependent Variable & \multicolumn{3}{|c|}{ Unemployment Incidence } \\
\hline Specification & 1 & 2 & 3 \\
\hline $\mathrm{POST} \times \mathrm{LBO}$ & $\begin{array}{r}0.002 \\
(0.34)\end{array}$ & $\begin{array}{r}0.001 \\
(0.37)\end{array}$ & $\begin{array}{r}4.613 \mathrm{e}-04 \\
(0.12)\end{array}$ \\
\hline $\mathrm{LBO}$ & $\begin{array}{l}-0.001 \\
(-0.18)\end{array}$ & $\begin{array}{r}-4.023 \mathrm{e}-04 \\
(-0.16)\end{array}$ & $\begin{array}{r}0.001 \\
(0.46)\end{array}$ \\
\hline POST & $\begin{array}{r}-0.036^{* * *} \\
(-10.00)\end{array}$ & $\begin{array}{r}-0.035^{* * *} \\
(-14.14)\end{array}$ & $\begin{array}{r}-0.030^{* * *} \\
(-8.82)\end{array}$ \\
\hline $\begin{array}{l}\text { Controls } \\
\text { Individual } \\
\text { Firm } \\
\text { Industry FE } \\
\text { County FE } \\
\text { Year FE }\end{array}$ & $\begin{array}{l}\text { No } \\
\text { No } \\
\text { No } \\
\text { No } \\
\text { No }\end{array}$ & $\begin{array}{l}\text { Yes } \\
\text { No } \\
\text { No } \\
\text { No } \\
\text { No }\end{array}$ & $\begin{array}{l}\text { Yes } \\
\text { Yes } \\
\text { Yes } \\
\text { Yes } \\
\text { Yes }\end{array}$ \\
\hline $\begin{array}{l}\text { Average Unemployment Incidence } \\
\text { Percentage Change } \\
R^{2}\end{array}$ & $\begin{array}{r}11.6 \% \\
0.02 \% \\
0.3 \%\end{array}$ & $\begin{array}{l}11.6 \% \\
0.01 \% \\
27.4 \%\end{array}$ & $\begin{array}{l}11.6 \% \\
0.00 \% \\
27.8 \%\end{array}$ \\
\hline $\begin{array}{l}\text { Workers } \\
\text { Observations }\end{array}$ & $\begin{array}{r}172253 \\
1540431\end{array}$ & $\begin{array}{r}172253 \\
1540431\end{array}$ & $\begin{array}{r}172253 \\
1540431\end{array}$ \\
\hline
\end{tabular}




\section{Table 4: Automation}

This table reports coefficient estimates and t-values (in parentheses) from regressions that explain unemployment incidence. The regressions correspond to the regressions in Column 3 of Table 3. We restrict our attention to buyouts announced from 2002 to 2008. In addition, we cluster the standard errors at the firm-municipality level. The average unemployment incidence refers to the average unemployment incidence for treated workers before $t=1$. The percentage change is the coefficient on POST $\times L B O$ divided by the average unemployment incidence. Panel A reports estimates by routine and non-routine occupations based on the occupation classification in Goos et al. (2014). This classification is also available in Table A4. Panels B and C report estimates for workers in treated and control firms that have a value added per employee at $t=0$ above/below the median in the two-digit industry they operate in. A plot of trends in unemployment incidence for routine and non-routine workers in ex ante low-productivity firms is available in Figure A1. We denote statistical significance at the $1 \%$ level by $* * *$ and statistical significance at the $5 \%$ level by $* *$.

\begin{tabular}{|c|c|c|c|}
\hline \multicolumn{4}{|l|}{ Panel A: Routine Intensity } \\
\hline Specification & Baseline & Routine & Non-routine \\
\hline \multirow{3}{*}{$\mathrm{POST} \times \mathrm{LBO}$} & 1 & 2 & 3 \\
\hline & -0.004 & 0.010 & $-0.012^{* *}$ \\
\hline & $(-0.82)$ & $(1.35)$ & $(-2.23)$ \\
\hline Average Unemployment Incidence & $9.8 \%$ & $9.4 \%$ & $10.1 \%$ \\
\hline Percentage Change & $-4.1 \%$ & $10.6 \%$ & $-11.9 \%$ \\
\hline$R^{2}$ & $25.5 \%$ & $24.7 \%$ & $26.3 \%$ \\
\hline Workers & 87615 & 35020 & 52595 \\
\hline Observations & 783733 & 313731 & 470002 \\
\hline \multicolumn{4}{|c|}{ Panel B: Ex-Ante Low-productivity Firms } \\
\hline \multirow[t]{2}{*}{ Specification } & Baseline & Routine & Non-routine \\
\hline & 1 & 2 & 3 \\
\hline \multirow[t]{2}{*}{$\mathrm{POST} \times \mathrm{LBO}$} & -0.005 & $0.066^{* * *}$ & $-0.024^{* * *}$ \\
\hline & $(-1.24)$ & (3.18) & $(-2.93)$ \\
\hline Average Unemployment Incidence & $14.3 \%$ & $10.5 \%$ & $15.3 \%$ \\
\hline Percentage Change & $-6.3 \%$ & $62.9 \%$ & $-15.7 \%$ \\
\hline$R^{2}$ & $26.3 \%$ & $24.8 \%$ & $27.2 \%$ \\
\hline Workers & 30593 & 6533 & 24060 \\
\hline Observations & 273213 & 58472 & 214741 \\
\hline \multicolumn{4}{|c|}{ Panel C: Ex-Ante High-productivity Firms } \\
\hline \multirow[t]{2}{*}{ Specification } & Baseline & Routine & Non-routine \\
\hline & 1 & 2 & 3 \\
\hline \multirow{2}{*}{$\mathrm{POST} \times \mathrm{LBO}$} & -0.002 & -0.003 & -0.002 \\
\hline & $(-0.43)$ & $(-0.32)$ & $(-0.47)$ \\
\hline Average Unemployment Incidence & $7.3 \%$ & $9.1 \%$ & $5.8 \%$ \\
\hline Percentage Change & $-2.7 \%$ & $-3.3 \%$ & $-3.4 \%$ \\
\hline$R^{2}$ & $25.0 \%$ & $24.9 \%$ & $24.9 \%$ \\
\hline Workers & 57022 & 28487 & 28535 \\
\hline Observations & 510520 & 255259 & 255261 \\
\hline
\end{tabular}




\section{Table 5: Offshoring}

This table reports the coefficient estimates and t-values (in parentheses) from regressions that explain unemployment incidence. The regressions correspond to the regression in Column 3 of Table 3 . We restrict our attention to buyouts announced between 2002 and 2008. In addition, we cluster the standard errors at the firm-municipality level. Average unemployment incidence refers to the average unemployment incidence for treated workers before $t=1$. The percentage change is the coefficient on $P O S T \times L B O$ divided by the average unemployment incidence. Panel A reports estimates of offshorable and non-offshorable jobs based on the classifications described in Goos et al. (2014). This classification is also available in Table A4. Panels B and C report estimates for workers in treated and control firms with the value added per employee at $t=0$ below/above the median in the two-digit industry in which they operate. A plot of the trends in unemployment incidence for offshorable and non-offshorable workers in ex ante low-productivity firms is available in Figure A1. We denote statistical significance at the $1 \%$ level by $* * *$ and statistical significance at the $5 \%$ level by $* *$.

\begin{tabular}{|c|c|c|c|}
\hline \multicolumn{4}{|l|}{ Panel A: Offshorability } \\
\hline Specification & Baseline & Offshorable & Non-offshorable \\
\hline \multirow{3}{*}{$\mathrm{POST} \times \mathrm{LBO}$} & 1 & 2 & 3 \\
\hline & -0.004 & 0.001 & -0.005 \\
\hline & $(-0.82)$ & $(0.11)$ & $(-0.91)$ \\
\hline Average Unemployment Incidence & $9.8 \%$ & $7.6 \%$ & $11.1 \%$ \\
\hline Percentage Change & $-4.1 \%$ & $1.3 \%$ & $-4.5 \%$ \\
\hline$R^{2}$ & $25.5 \%$ & $22.6 \%$ & $27.3 \%$ \\
\hline Workers & 87615 & 33091 & 54524 \\
\hline Observations & 783733 & 296274 & 487459 \\
\hline \multicolumn{4}{|c|}{ Panel B: Ex-Ante Low-productivity Firms } \\
\hline \multirow[t]{2}{*}{ Specification } & Baseline & Offshorable & Non-offshorable \\
\hline & 1 & 2 & 3 \\
\hline \multirow[t]{2}{*}{$\mathrm{POST} \times \mathrm{LBO}$} & -0.009 & $0.048^{* * *}$ & $-0.020^{* *}$ \\
\hline & $(-1.11)$ & $(3.50)$ & $(-2.28)$ \\
\hline Average Unemployment Incidence & $14.3 \%$ & $8.6 \%$ & $15.7 \%$ \\
\hline Percentage Change & $-6.3 \%$ & $55.8 \%$ & $-12.7 \%$ \\
\hline$R^{2}$ & $26.3 \%$ & $23.7 \%$ & $27.3 \%$ \\
\hline Workers & 30593 & 6336 & 24257 \\
\hline Observations & 273213 & 56707 & 216506 \\
\hline \multicolumn{4}{|c|}{ Panel C: Ex-Ante High-productivity Firms } \\
\hline \multirow[t]{2}{*}{ Specification } & Baseline & Offshorable & Non-offshorable \\
\hline & 1 & 2 & 3 \\
\hline \multirow{2}{*}{$\mathrm{POST} \times \mathrm{LBO}$} & -0.002 & -0.012 & 0.008 \\
\hline & $(-0.43)$ & $(-1.56)$ & $(1.35)$ \\
\hline Average Unemployment Incidence & $7.3 \%$ & $7.3 \%$ & $7.3 \%$ \\
\hline Percentage Change & $-2.7 \%$ & $-16.4 \%$ & $11.0 \%$ \\
\hline$R^{2}$ & $25.0 \%$ & $22.6 \%$ & $27.3 \%$ \\
\hline Workers & 57022 & 26755 & 30267 \\
\hline Observations & 510520 & 239567 & 270953 \\
\hline
\end{tabular}


Table 6: Tougher Bargaining with Labor Unions

This table reports coefficient estimates and t-values (in parentheses) from regressions that explain unemployment incidence. The regressions correspond to the regression in Column 3 of Table 3. We clustered the standard errors at the firm-municipality level. Average unemployment incidence refers to the average unemployment incidence for treated workers before $t=1$. The percentage change is the coefficient of POST $\times$ LBO divided by the average unemployment incidence. Panel A reports estimates by workers that are employed in industries with aggressive and non-aggressive unions. We base the classification of industries on Lindberg (2006) and Cronqvist et al. (2009). Panels $\mathrm{B}$ and $\mathrm{C}$ report estimates for workers in treated and control firms that have a leverage ratio at $t=0$ below/above the median in the two-digit industry in which they operate. Panel D reports estimates for blue-collar and white-collar workers in treated firms with low leverage at $t=0$ and in industries with aggressive unions. Blue-collar workers are workers with fewer than two years of post-secondary education, and white-collar workers are workers with two or more years of post-secondary education. A plot of pre-trends and post-trends for subcategories in Panel D is available in Figure A1. We denote statistical significance at the $5 \%$ level by $* *$.

\begin{tabular}{|c|c|c|c|}
\hline \multicolumn{4}{|l|}{ Panel A: Union Aggressiveness } \\
\hline Specification & Baseline & Aggressive & Non-aggressive \\
\hline \multirow{3}{*}{$\mathrm{POST} \times \mathrm{LBO}$} & 1 & 2 & 3 \\
\hline & $4.613 \mathrm{e}-04$ & 0.012 & -0.001 \\
\hline & $(0.12)$ & $(1.64)$ & $(-0.16)$ \\
\hline Average Unemployment Incidence & $11.6 \%$ & 0.084 & 0.118 \\
\hline Percentage Change & $0.00 \%$ & $14.3 \%$ & $-0.8 \%$ \\
\hline$R^{2}$ & $27.8 \%$ & $34.1 \%$ & $27.5 \%$ \\
\hline Workers & 172253 & 11505 & 160848 \\
\hline Observations & 1540431 & 103025 & 1437406 \\
\hline \multicolumn{4}{|l|}{ Panel B: Ex Ante Low-leverage Firms } \\
\hline \multirow[t]{2}{*}{ Specification } & Baseline & Aggressive & Non-aggressive \\
\hline & 1 & 2 & 3 \\
\hline \multirow{2}{*}{$\mathrm{POST} \times \mathrm{LBO}$} & 0.006 & $0.018^{* *}$ & 0.004 \\
\hline & $(0.80)$ & $(2.11)$ & $(0.44)$ \\
\hline Average Unemployment Incidence & $10.7 \%$ & $7.8 \%$ & $11.3 \%$ \\
\hline Percentage Change & $5.6 \%$ & $23.1 \%$ & $3.5 \%$ \\
\hline$R^{2}$ & $27.6 \%$ & $33.8 \%$ & $26.6 \%$ \\
\hline Workers & 59296 & 9259 & 50037 \\
\hline Observations & 530934 & 82970 & 447964 \\
\hline \multicolumn{4}{|l|}{ Panel C: Ex Ante High-leverage Firms } \\
\hline \multirow[t]{2}{*}{ Specification } & Baseline & Aggressive & Non-aggressive \\
\hline & 1 & 2 & 3 \\
\hline \multirow[t]{2}{*}{$\mathrm{POST} \times \mathrm{LBO}$} & -0.002 & -0.013 & -0.002 \\
\hline & $(-0.50)$ & $(0.017)$ & $(-0.48)$ \\
\hline Average Unemployment Incidence & $12.0 \%$ & $12.1 \%$ & $12.0 \%$ \\
\hline Percentage Change & $-1.7 \%$ & $-10.7 \%$ & $-1.7 \%$ \\
\hline$R^{2}$ & $28.1 \%$ & $35.5 \%$ & $27.9 \%$ \\
\hline Workers & 113057 & 2246 & 110811 \\
\hline Observations & 1009497 & 20055 & 989442 \\
\hline
\end{tabular}

Continued on next page. 
Continued from previous page.

\begin{tabular}{lrrr}
\hline \multicolumn{3}{l}{ Panel D: Worker Type (Ex Ante Low-leverage and Aggressive Unions) } \\
\hline Specification & Baseline & Blue-collar & White-collar \\
& 1 & 2 & 3 \\
\cline { 2 - 4 } POST $\times$ LBO & $0.018^{* *}$ & $0.018^{* *}$ & -0.001 \\
& $(2.11)$ & $(2.02)$ & $(-0.05)$ \\
Average Unemployment Incidence & & & \\
Percentage Change & $7.8 \%$ & $7.6 \%$ & $13.0 \%$ \\
$R^{2}$ & $23.1 \%$ & $23.7 \%$ & $-0.8 \%$ \\
Workers & $33.8 \%$ & $34.3 \%$ & $28.9 \%$ \\
Observations & 9259 & 8553 & 706 \\
& 82970 & 76667 & 6303 \\
\hline
\end{tabular}




\section{Table 7: Firm-level Estimates}

This table reports the coefficient estimates and their associated t-values (in parentheses) from regressions at the firm level for different outcome variables. All regressions use standard errors clustered at the firm level and are weighted by firm size (as of time zero). Variable descriptions are available in Table A1. The firm controls are the same as those included in the propensity score in Table A2, excluding firm size and the dependent variable if it appears as a control in Table A2. We base the industry-fixed effects on the Statistics Sweden SNI2002 industry classification at the two-digit level (45 dummies). In addition, we base the county-fixed effects on the location of the firm (20 dummies). Plots of the pre-trends and post-trends of the variables are shown in Figure 2. We denote statistical significance at the $1 \%$ level by ${ }^{* * *}$, statistical significance at the $5 \%$ level by ${ }^{* *}$, and statistical significance at the $10 \%$ level by $*$.

\begin{tabular}{|c|c|c|c|c|}
\hline \multicolumn{5}{|c|}{ Panel A: All Firms } \\
\hline \multirow[b]{3}{*}{$\mathrm{POST} \times \mathrm{LBO}$} & Log(Size) & $\log (\#$ Est $)$ & $\log (1+\operatorname{Sep})$ & $\log (1+$ Hir $)$ \\
\hline & 1 & 2 & 3 & 4 \\
\hline & $\begin{array}{r}0.0701 \\
(1.64)\end{array}$ & $\begin{array}{r}0.0271 \\
(0.37)\end{array}$ & $\begin{array}{r}0.176 \\
(0.85)\end{array}$ & $\begin{array}{r}0.157^{*} \\
(1.88)\end{array}$ \\
\hline \multirow{4}{*}{$\begin{array}{l}R^{2} \\
\text { Observations }\end{array}$} & $61.1 \%$ & $55.0 \%$ & $46.6 \%$ & $65.8 \%$ \\
\hline & 7064 & 7064 & 7064 & 7064 \\
\hline & $\log ($ Sales $)$ & $\log (\mathrm{FA})$ & $\log (\mathrm{VA} / \mathrm{Emp})$ & $\mathrm{ROA}$ \\
\hline & 5 & 6 & 7 & 8 \\
\hline $\mathrm{POST} \times \mathrm{LBO}$ & $\begin{array}{r}0.077 \\
(1.28)\end{array}$ & $\begin{array}{l}-0.104 \\
(-0.62)\end{array}$ & $\begin{array}{r}0.044^{*} \\
(1.69)\end{array}$ & $\begin{array}{r}0.012 \\
(1.05)\end{array}$ \\
\hline$R^{2}$ & $58.3 \%$ & $50.5 \%$ & $60.3 \%$ & $44.9 \%$ \\
\hline Observations & 6765 & 6765 & 6461 & 6763 \\
\hline \multicolumn{5}{|c|}{ Panel B: Ex Ante Low-productivity Firms } \\
\hline & $\log ($ Size $)$ & $\log (\#$ Est $)$ & $\log (1+\operatorname{Sep})$ & $\log (1+$ Hir $)$ \\
\hline & 17 & 18 & 19 & 20 \\
\hline POST $\times$ LBO & $\begin{array}{r}0.047 \\
(0.67)\end{array}$ & $\begin{array}{l}-0.180 \\
(-1.17)\end{array}$ & $\begin{array}{r}0.431 \\
(0.87)\end{array}$ & $\begin{array}{r}0.063 \\
(0.39)\end{array}$ \\
\hline \multirow{4}{*}{$\begin{array}{l}R^{2} \\
\text { Observations }\end{array}$} & 82.0 & $65.4 \%$ & $54.3 \%$ & $81.6 \%$ \\
\hline & 1767 & 1767 & 1767 & 1767 \\
\hline & Log(Sales) & $\log (F A)$ & $\log (\mathrm{VA} / \mathrm{Emp})$ & $\mathrm{ROA}$ \\
\hline & 21 & 22 & 23 & 24 \\
\hline $\mathrm{POST} \times \mathrm{LBO}$ & $\begin{array}{r}0.311^{* * *} \\
(2.86)\end{array}$ & $\begin{array}{r}0.309 \\
(0.77)\end{array}$ & $\begin{array}{r}0.102^{* * *} \\
(2.60)\end{array}$ & $\begin{array}{r}0.047^{*} \\
(1.93)\end{array}$ \\
\hline$R^{2}$ & $73.3 \%$ & $52.6 \%$ & $57.8 \%$ & $55.0 \%$ \\
\hline Observations & 1709 & 1709 & 1504 & 1708 \\
\hline
\end{tabular}

Continued on next page. 
Continued from previous page.

\begin{tabular}{|c|c|c|c|c|}
\hline \multicolumn{5}{|c|}{ Panel C: Ex Ante High-productivity Firms } \\
\hline & $\log ($ Size $)$ & $\log (\#$ Est $)$ & $\log (1+\operatorname{Sep})$ & $\log (1+$ Hir $)$ \\
\hline & 9 & 10 & 11 & 12 \\
\hline $\mathrm{POST} \times \mathrm{LBO}$ & $\begin{array}{r}0.119^{* * * *} \\
(2.87)\end{array}$ & $\begin{array}{r}0.135^{* *} \\
(2.18)\end{array}$ & $\begin{array}{r}0.126 \\
(0.99)\end{array}$ & $\begin{array}{r}0.200^{* *} \\
(2.27)\end{array}$ \\
\hline \multirow{4}{*}{$\begin{array}{l}R^{2} \\
\text { Observations }\end{array}$} & 57.4 & $57.5 \%$ & $52.3 \%$ & $55.5 \%$ \\
\hline & 5297 & 5297 & 5297 & 5297 \\
\hline & Log(Sales) & $\log (\mathrm{FA})$ & $\log (\mathrm{VA} / \mathrm{Emp})$ & ROA \\
\hline & 13 & 14 & 15 & 16 \\
\hline $\mathrm{POST} \times \mathrm{LBO}$ & $\begin{array}{r}0.027 \\
(0.45)\end{array}$ & $\begin{array}{l}-0.145 \\
(-1.11)\end{array}$ & $\begin{array}{r}0.026 \\
(0.89)\end{array}$ & $\begin{array}{l}-0.001 \\
(-0.03)\end{array}$ \\
\hline$R^{2}$ & $60.5 \%$ & $59.4 \%$ & $59.3 \%$ & $42.5 \%$ \\
\hline Observations & 5056 & 5056 & 4957 & 5055 \\
\hline
\end{tabular}




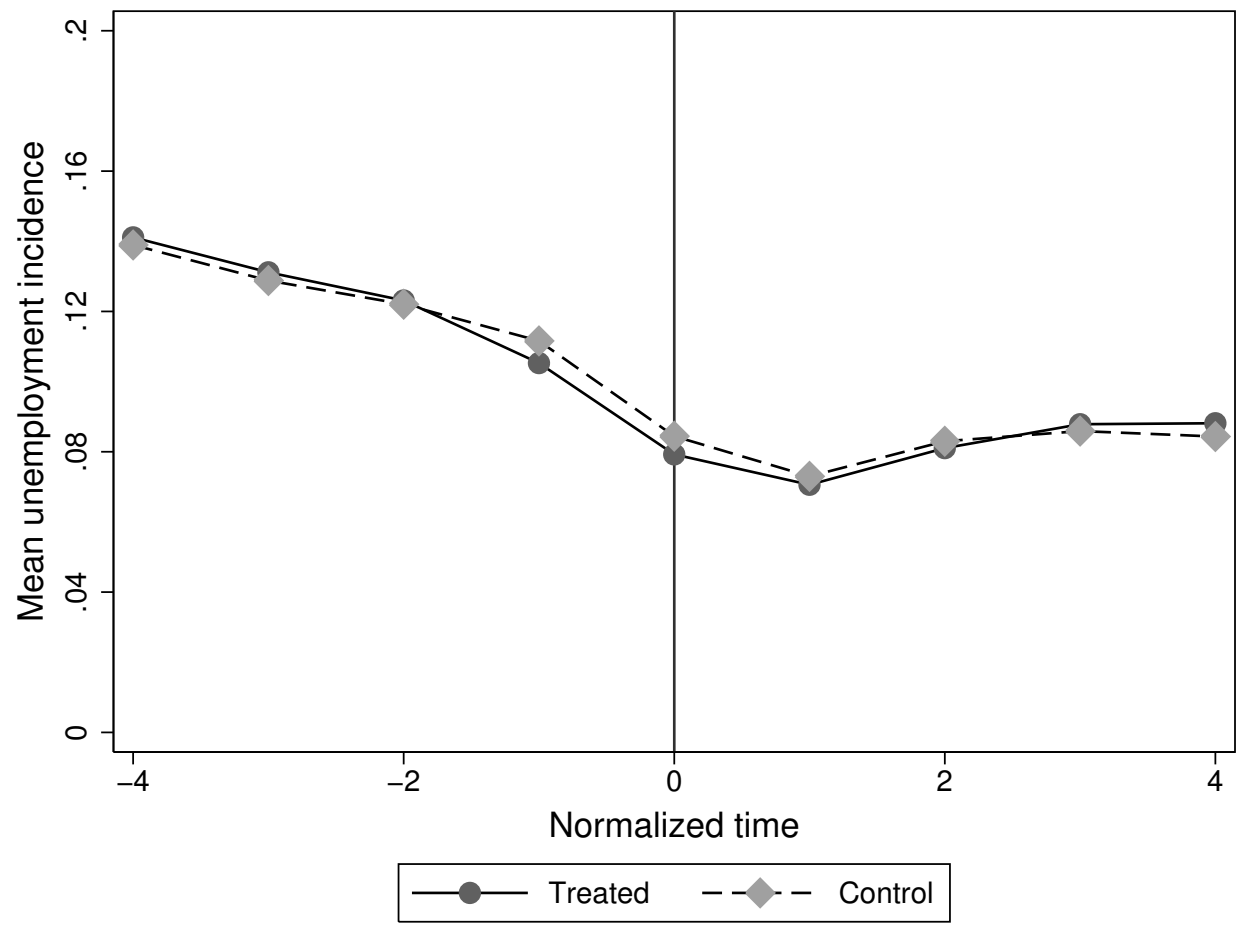

Figure 1: Trends in Unemployment Incidence

This figure displays pre- and post-treatment trends in average unemployment incidence for the treated and control workers. The buyout is announced at $t=1$. 

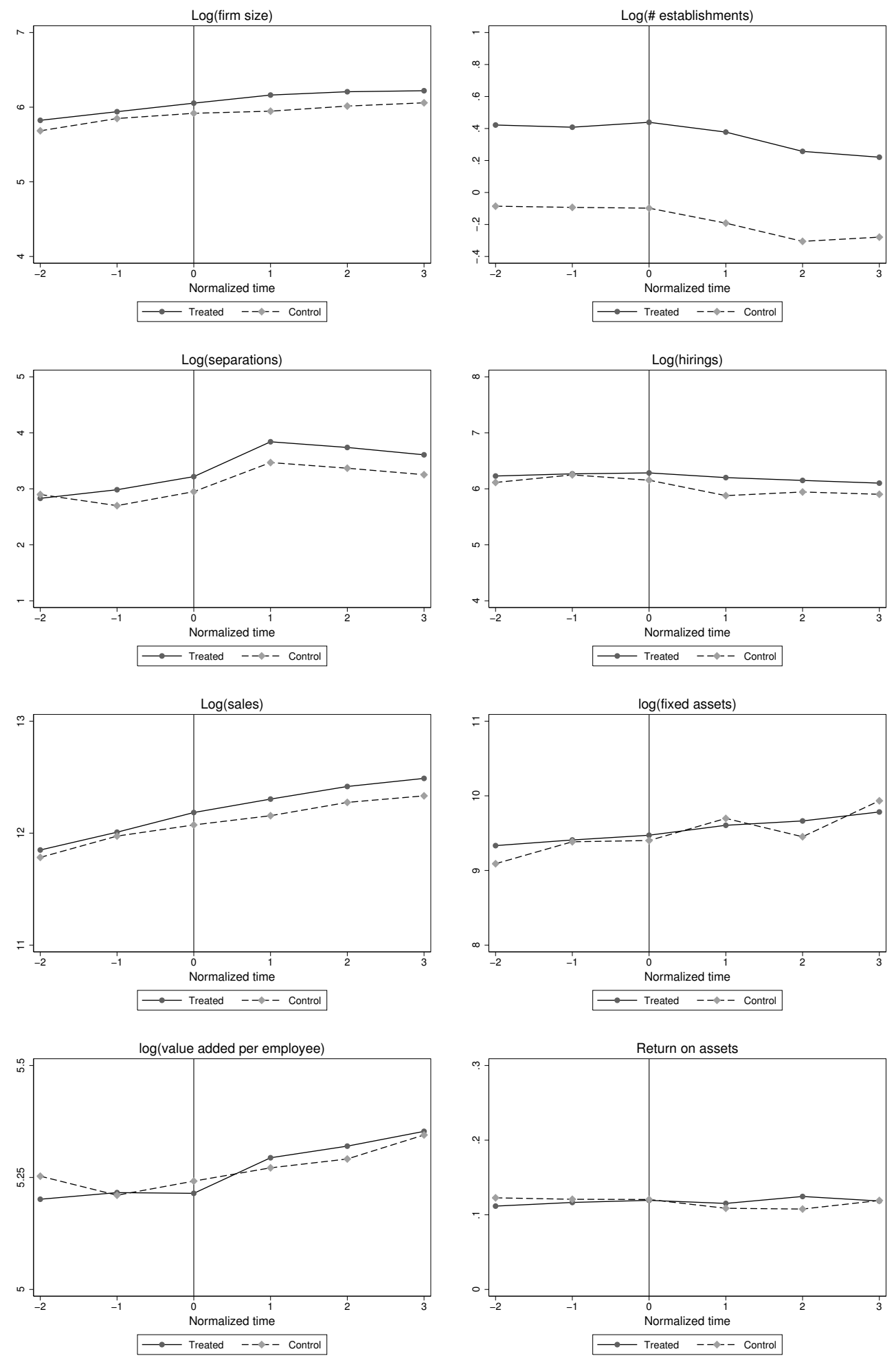

Figure 2: Trends in Firm-level Variables

This figure displays the pre- and post-treatment trends in normalized average firm-level variables for treated and control firms. The normalized averages represent group-time effects from the regression models that control for same firm covariates as shown in Table A2. Variable descriptions are available in Table A1. The buyout is announced at $t=1$. 


\section{Appendix}

\section{A The Swedish Private Equity Market}

In this section, we discuss the Swedish private equity market and how it compares to markets elsewhere. The evidence suggests that the goals of buyouts in Sweden are similar to those of buyouts elsewhere. First, the Swedish private equity market evolved in response to a wave of buyouts in the United States. In 1986, the first Nordic private equity company, Procuritas, was established. In 1989, IK Investment Partners (then Scandinavian Acquisition Capital Fund and later Industri Kapital) and Nordic Capital were founded, with EQT following in 1994. Since then, the Swedish private equity market has become one of the largest in Europe. In 2006, Sweden had the highest level of private equity investments as a percentage of GDP according to Lerner et al. (2008). During the period from 2007 to 2012, Nordic Capital raised 7.7 billion USD for their funds, and EQT Partners raised 6.2 billion USD, which ranked them as the 25th and 40th largest funds worldwide (Private Equity International), respectively. Anecdotal evidence supports the notion that the business model of Swedish private equity firms is similar to that of their U.S. counterparts. For example, EQT states, "Sales growth and margin expansion are achieved through multiple strategies, including geographic expansion, new products, acquisitions and strategic reorientation. [... Almost all of the returns on investments are attributed to operational improvements such as increases in sales and efficiency gains." In comparison, Bain Capital Private Equity (ranked 9th by Private Equity International) states that they "help companies improve their competitive position by expanding into new products and markets, growing productivity and strengthening their organizations." Additionally, private equity industry associations in Sweden and elsewhere (such as the European Venture Capital Association and the Swedish Venture Capital Association) state similar targets for private equity buyouts, such as "mature companies with development potential and in need of an active owner with financial strength."

Second, the Swedish buyout market has evolved much like the markets in other countries. Furthermore, the Swedish market has a high presence of international private equity funds. Table 1 shows that the majority of all transactions are corporate divestitures and management buyouts in Sweden, the United States, the United Kingdom, and France. However, in Sweden, more than 30\% 
of all buyouts are cross-border transactions. Although this percentage is lower than that in the United States, the average transaction values for the buyouts are similar for Sweden, the United Kingdom, and France. In all four countries, the number of buyouts increased by more than $60 \%$ between 1999 and 2008. Thus, the Swedish private equity market shares several features with the private equity markets in the United States, the United Kingdom, and France.

Finally, holding periods and the performance of target firms are not very different between Swedish buyouts and buyouts elsewhere. Bergström et al. (2007) report a median holding period of 4.5 years for Swedish buyouts that were undertaken between 1993 and in the first half of 2006 . In comparison, Kaplan and Strömberg (2009) report a median holding period of six years for transactions worldwide between 1970 and 2007. The shorter holding period in Sweden can partly be explained by an active initial public offering market during the period. Regarding performance, Bergström et al. (2007) report evidence of operating improvements in the EBITDA margin of approximately three percentage points. Furthermore, profitability improvements are observed for the U.S. (Kaplan, 1989), France Boucly et al. (2011), and Western Europe (Acharya et al., 2013). The higher profitability in the wake of buyouts is also consistent with evidence in Lopez de Silanes et al. (2014). The authors document that the median internal rate of return (IRR) for transactions in Scandinavia was $24 \%$ and only $22 \%$ in the United States, $21 \%$ in the United Kingdom, and $22 \%$ in France. Moreover, the number of investments with IRR above $50 \%$ was $31 \%$ in Scandinavia and only $27 \%$ in the United States, $25 \%$ in the United Kingdom, and $21 \%$ in France.

\section{B Capital IQ}

Our starting point in the Capital IQ database is transactions in which the target's geographical location is Sweden and the announcement date is between 1999 and 2008. We begin from 1999 because firm-level information from the Swedish Companies Registrations Office is available from 1998 onwards. The period ends in 2008 to ensure that we obtain four post-periods of individual-level information (the matched employer-employee data end in 2011).

We then apply a similar selection criteria as Strömberg (2008). We select all transactions with secondary transaction features tagged as "Leveraged Buy Out" or "Management Buyout" 
and those with a buyer/investor stage of interest of "Buyout". ${ }^{38}$ Next, we keep the transactions marked as "Closed" or "Effective" and remove the transactions that involved minority stakes and private investments in public equity. In addition, we remove the transactions marked as secondary buyouts. This procedure leaves us with 478 buyouts that were obtained from the Capital IQ database.

To the list, we add 33 buyouts that were identified by Bergström et al. (2007) but not by Capital IQ. Overall, we identify 511 buyouts. Next, we match the names to merge the buyout information to the firm-level data from the Swedish Companies Registrations Office. The firm-level data contain legal firm identifiers we use to merge the data to the LISA database. Overall, we are able to match 454 target firms.

Next, we correct for the corporate group structure of the target firms by marking subsidiaries to buyout targets as treated. We match one year before the announcement of the buyout to ensure that the group structure is not affected by the buyout itself. Because some buyouts occur in newly created holding companies, using the lagged group structure reduces the sample to 369 buyouts. The data reveal that there are six secondary buyouts that Capital IQ did not mark as secondary buyouts. We disregard these buyouts and 12 other buyouts that did not have firm-level characteristics one year before the buyout.

\section{Propensity Score Matching}

We use propensity score matching to create our control group of firms. In contrast to cell matching, propensity score matching allows us to match firms based on several characteristics without encountering the problem of dimensionality. The firm characteristics we match on include the following: fixed assets, sales, firm age, value added per employee, firm growth, whether a firm was established in several industries, the standard deviation of worker wages, return on assets, debt to assets, average worker age and average worker tenure. Matching is performed within strata of firm

\footnotetext{
${ }^{38}$ Capital IQ defines a buyout as follows: "This feature is assigned when a financial sponsor acquires a mature business by combining equity with debt, raised by leveraging the business. This is only applicable: [i)] To strategic buyer transactions when it is explicitly mentioned in the press release. [ii)] To transactions where a majority stake is being acquired (i.e. 50\% or more)." Capital IQ defines a transaction as closed when the transaction has been closed. However, no hard information is available regarding whether this transaction is effective. An effective transaction is one that has been closed and in which Capital IQ has found information that indicates it is effective. In practice, all closed transactions should be effective unless the transaction is recent.
} 
size, firm age, year and industry bins. ${ }^{39}$ See Table A1 for variable descriptions.

The matching algorithm that we chose is one-to-one nearest neighbor matching without replacement. The extensive available dataset motivates nearest neighbor matching in comparison with kernel matching and local linear matching, which use all observations in the pool of potential controls. In our setting, using the entire pool of potential control firms involves an analysis of more than one million firms and their employees with unclear pre- and post-treatment periods. Computational restrictions make estimation unfeasible when using such a large dataset. Furthermore, we use a one-to-one match because the pool of good matches for several firm characteristics is a function of the characteristics themselves. For instance, although firm size is an important predictor of the probability of undergoing a buyout, the distribution of firm size is skewed with many small firms and few large firms. Consequently, finding multiple matches for smaller firms is easier than finding them for larger firms. One limitation with one-to-one matching is that the reduced bias comes at the expense of increased variance when one control firm is used for each treated firm (Smith and Todd, 2005). Table A3 in the Appendix shows that our main results are similar if we use one-to-four propensity score matching. The large number of potential control firms in our data allows us to match without replacement to increase the precision of our estimates.

We begin with all limited-liability firms in Sweden as potential controls and exclude firms that are the targets of mergers or acquisitions during the analyzed period. To find targets for mergers and acquisitions, we rely on data from the Bureau van Dijk's Zephyr database. We collect information on all mergers and acquisitions that have target firms located in Sweden and match the names to find firm and legal identifiers for each target firm in the SCRO data. The initial sample from the Zephyr database contains 6,525 target firms, and we are able to find firm identifiers for 6,061 of these firms. We remove these firms from the set of potential control firms.

Column 1 of Table A2 presents the results from the first stage of the probit regression that explain the probability that a firm will undergo a buyout. We obtain estimated propensity scores for 760 target firms involved in 351 buyouts and for 1,039,365 potential control firms. The number of targeted firms is larger than the number of buyouts because we treat subsidiaries as separate

\footnotetext{
${ }^{39}$ The firm size bins are fewer than 21 employees, 21 to 40 employees, 41 to 70 employees, 71 to 100 employees, 101 to 150 employees, 151 to 300 employees, 301 to 500 employees, 501 to 1,000 employees, 1,001 to 1,500 employees and 1,500 to 3,500 employees. The firm age bins are fewer than 5 years, 5 to 7 years, 8 to 12 years, 13 to 16 years and 17 to 21 years.
} 
entities. The variables are jointly statistically significant, and the pseudo- $R^{2}$ is $10.5 \%$. Column 2 presents the results from the same probit regression, where the sample is restricted to the one-toone nearest neighbor matches. The variables are no longer jointly statistically significant, and the pseudo- $R^{2}$ is reduced from $10.5 \%$ to $1.4 \%$. The low pseudo- $R^{2}$ and the joint insignificance of the variables suggest that the matched control group and the treatment groups are similar regarding their observable pre-treatment characteristics. 


\section{Table A1: Variable Definitions}

This table displays descriptions of the variables that we use from the Statistics Sweden's LISA database and from the Swedish Companies Registrations Office (SCRO). The Swedish Secrecy Act protects access to the data from Statistics Sweden, but researchers affiliated with a Swedish research institution can apply for access. A full detailed description of the variables in LISA is available from the Statistics Sweden homepage (scb.se). An individual's main source of income in November in each year is the base for the majority of the employer-employee links in LISA. The SCRO data can be purchased from SCRO (bolagsverket.se) or in consolidated form from the consulting company Bisnode (bisnode.se). The annual accounts of the firms do not need to correspond to the calendar years. When merging the SCRO data with the LISA database, we merge on the basis of the year obtained from the end date of the financial accounts. Firms can submit many annual accounts each year. This occurs if the length of the accounting year changes or if the firms make corrections to their annual account. We always use the latest annual account information for a given year.

\begin{tabular}{|c|c|c|}
\hline \multicolumn{3}{|c|}{ Panel A: Worker-level Variables } \\
\hline Variable & Source & Notes \\
\hline Individual Identifier & LISA & Original source is social security numbers from the population registry. \\
\hline Age & LISA & Original source is the population registry. \\
\hline Annual Labor Income & LISA & $\begin{array}{l}\text { Original source is Swedish Tax Office records. Annual labor income } \\
\text { refers to total gross annual labor income from all sources. }\end{array}$ \\
\hline Gender & LISA & Original source is the population registry. \\
\hline Skill & LISA & $\begin{array}{l}\text { Information on highest completed education level comes from the Ed- } \\
\text { ucation Register at Statistics Sweden (Utbildningsregistret). The ed- } \\
\text { ucation level variable is on a scale from } 1 \text { to } 6 \text { corresponding to: } 6 \text {. } \\
\text { Postgraduate education; } 5 \text {. Post-secondary education, two years or } \\
\text { longer; } 4 \text {. Post-secondary education, less than two years; } 3 \text {. Upper } \\
\text { secondary education; } 2 \text {. Primary and lower secondary education; } 9 \text { or } \\
10 \text { years; and } 1 \text {. Primary and lower secondary education, less than } 9 \\
\text { years. We define a worker as skilled if he or she has at least two years } \\
\text { of post-secondary education. }\end{array}$ \\
\hline Tenure & LISA & $\begin{array}{l}\text { We calculate the tenure of a worker based on observing worker-firm } \\
\text { links between the years } 1990 \text { and } 2011 \text {. A worker can thus have a } \\
\text { maximum tenure of } 20 \text { years. }\end{array}$ \\
\hline Days of Unemployment & LISA & $\begin{array}{l}\text { Statistics Sweden calculates the yearly number of days in unemploy- } \\
\text { ment based on registry data from Arbetsförmedlingen (Swedish Public } \\
\text { Employment Service). Registering at Arbetsförmedlingen is manda- } \\
\text { tory for receiving unemployment benefits. An individual is designated } \\
\text { as unemployed by Statistics Sweden if the person does not have a job, } \\
\text { is looking for a job but cannot find one, and is not registered as being } \\
\text { part of any government labor market policy program. }\end{array}$ \\
\hline
\end{tabular}

Continued on next page. 
Continued from previous next page.

\begin{tabular}{|c|c|c|}
\hline \multicolumn{3}{|c|}{ Panel A: Worker-level Variables } \\
\hline Variable & Source & Notes \\
\hline Occupation & LISA & $\begin{array}{l}\text { Information on occupation classification is available from } 2001 \text { onwards. } \\
\text { Swedish Standard Classification of Occupations (SSYK) is based on } \\
\text { the International Standard Classification of Occupations (ISCO- } 88 \text { ). } \\
\text { The SSYK data available from the LISA database come mainly from } \\
\text { the official wage statistics survey (Lönestrukturstatistiken) and from } \\
\text { supplementary surveys of firms (primarily with } 2-19 \text { employees) that } \\
\text { Statistics Sweden undertakes of firms not included in the official wage } \\
\text { survey. The sampling design in the supplementary surveys is a rolling } \\
\text { panel and all eligible firms are surveyed at least once every five years. } \\
\text { Occupation information is available for each year, but the information } \\
\text { may not be accurate for each year. To ensure that we have accurate } \\
\text { occupation information for every year, we require that the information } \\
\text { be collected in the relevant year and for the correct employer-employee }\end{array}$ \\
\hline
\end{tabular}
link.

\begin{tabular}{lll}
\hline Panel B: Firm-level Variables & & \\
\hline Variable & Source & Notes
\end{tabular}

Firm Identifier

Firm Size

Size Growth

Hirings

Separations

Number of Establishments

Diversification

Firm Age
FAD The FAD identifier is developed by Statistics Sweden to correct for potential administrative changes in firm legal identifiers over time. It is obtained from the Statistics Sweden FAD database (The Dynamics of Enterprises and Establishments Database). The principle behind the FAD identifiers is that they remain the same from one year to another if the firm identifiers have changed but a majority of workers are the same between the two years. The details of how Statistics Sweden calculates the FAD identifiers are outlined in Andersson and Arvidson (2006).

LISA Aggregated from individual level data in LISA.

LISA Following Davis et al. (2014), the growth rate of a firm between two years is calculated as $g_{i t}=\frac{\left(E_{i t}-E_{i t-1}\right)}{0.5\left(E_{i t}+E_{i t-1}\right)}$ where where $E_{i t}$ refers to the size of firm $i$ at time $t$.

LISA We calculate hirings by following workers over time. The number of hires refers to the number of workers in a firm that had a different firm FAD identifier last year (thus was newly hired).

LISA We calculate separations by following workers over time. The number of separations refers to the number of workers that was employed at the FAD identifier last year but not this year.

LISA Number of establishments is obtained by counting the number of establishments linked to a firm in each year.

LISA The diversification dummy is takes the value one if a firm has establishments in more than one five digit industry.

LISA The firm age is calculated as the number of years since the FAD firm identifier emerged in the data for the first time. Because the FAD database at statistics Sweden starts in 1986, the maximum age of a company in our data is 25 years. 
Continued from previous next page.

\begin{tabular}{|c|c|c|}
\hline \multicolumn{3}{|l|}{ Panel B: Firm-level Variables } \\
\hline Variable & Source & Notes \\
\hline Average Worker Wage & LISA & Aggregated from individual level data in LISA. \\
\hline SD of Worker Wage & LISA & $\begin{array}{l}\text { The standard deviation of worker age is aggregated from individual } \\
\text { level data in LISA. }\end{array}$ \\
\hline Average Worker Age & LISA & Aggregated from individual level data in LISA. \\
\hline Average Worker Tenure & LISA & Aggregated from individual level data in LISA \\
\hline Industry and Location & LISA & $\begin{array}{l}\text { Information on the industry and location of an establishment comes } \\
\text { from Statistics Sweden who assigns identifiers, industry, and location } \\
\text { codes to physical places of work (the underlying databases at Statistics } \\
\text { Sweden are the RAMS and the Företagsdatabasen databases). The } \\
\text { industry classification of firms and establishments changed in } 2002 \text { but } \\
\text { changes where minor at the aggregate } 17 \text {-category classification we use } \\
\text { in this paper. }\end{array}$ \\
\hline Fixed Assets & SCRO & Total fixed assets (tangible and intangible). \\
\hline Sales & SCRO & Total sales. \\
\hline Value Added per Employee & SCRO & $\begin{array}{l}\text { Value added per employee is calculated by Bisnode and is obtained by } \\
\text { adding up adjusted EBIT, deductions, and all labor costs in the firm } \\
\text { and then dividing by the number of full time workers in the firm. }\end{array}$ \\
\hline Debt to Assets & SCRO & Total long term debt (maturity over a year) divided by total assets. \\
\hline Return on Assets & SCRO & Return to assets is defined as profit before taxes divided by total assets. \\
\hline Group Structure & $\mathrm{SCRO}$ & $\begin{array}{l}\text { The group structure comes from consolidated financial accounts sub- } \\
\text { mitted by firms with subsidiaries. The group structure traces ownership } \\
\text { links between firms with more than } 50 \% \text { ownership in each other and al- } \\
\text { lows us to construct for each year a tree with a parent and subsidiaries, } \\
\text { subsidiaries to the subsidiaries, and so on. }\end{array}$ \\
\hline
\end{tabular}




\section{Table A2: Propensity Score Matching}

This table presents results from the first-stage probit regression with z-values in parentheses. Column 1 shows the results before restricting the sample to only treated and control firms, and Column 2 shows the results after the restriction. The standard errors are clustered at the firm level. Variable descriptions are available in Table A1. Statistical significance at the $1 \%$ level is denoted by $* * *$, statistical significance at the $5 \%$ level by $* *$, and statistical significance at the $10 \%$ level by *. For year-fixed effects and industry-fixed effects, three stars indicates that the dummies are jointly statistically significant at the $1 \%$ level.

\begin{tabular}{|c|c|c|}
\hline Variable & $\begin{array}{r}\text { Pre-match } \\
1\end{array}$ & $\begin{array}{r}\text { Post-match } \\
2\end{array}$ \\
\hline Size & $\begin{array}{r}0.003^{* * *} \\
(12.28)\end{array}$ & $\begin{array}{r}2.315 \mathrm{e}-04 \\
(0.72)\end{array}$ \\
\hline Size Square & $\begin{array}{r}-9.870 \mathrm{e}-07^{* * *} \\
(-5.75)\end{array}$ & $\begin{array}{r}-5.660 \mathrm{e}-08 \\
(-0.43)\end{array}$ \\
\hline Size Growth & $\begin{array}{l}-0.023 \\
(-1.14)\end{array}$ & $\begin{array}{r}-0.026 \\
(0.44)\end{array}$ \\
\hline Age & $\begin{array}{r}0.009 \\
(0.95)\end{array}$ & $\begin{array}{l}-0.034 \\
(-1.32)\end{array}$ \\
\hline Age Square & $\begin{array}{r}0.001^{*} \\
(1.76)\end{array}$ & $\begin{array}{r}0.001 \\
(0.62)\end{array}$ \\
\hline Fixed Assets & $\begin{array}{r}-1.700 \mathrm{e}-08 \\
(-0.36)\end{array}$ & $\begin{array}{r}3.650 \mathrm{e}-08 \\
(10.24)\end{array}$ \\
\hline Sales & $\begin{array}{r}-7.880 \mathrm{e}-08^{* *} \\
(-2.46)\end{array}$ & $\begin{array}{r}-2.250 \mathrm{e}-08 \\
(-0.35)\end{array}$ \\
\hline Diversification & $\begin{array}{r}0.244^{* * *} \\
(3.38)\end{array}$ & $\begin{array}{l}-0.023 \\
(-0.16)\end{array}$ \\
\hline Value Added per Employee & $\begin{array}{r}-1.810 \mathrm{e}-06^{* * *} \\
(-4.91)\end{array}$ & $\begin{array}{r}1.550 \mathrm{e}-05 \\
(-0.40)\end{array}$ \\
\hline Debt to Assets & $\begin{array}{r}-0.274^{* * *} \\
(-4.58)\end{array}$ & $\begin{array}{r}0.296 \\
(1.61)\end{array}$ \\
\hline Return on Assets & $\begin{array}{l}-0.001 \\
(-1.59)\end{array}$ & $\begin{array}{r}0.027 \\
(0.35)\end{array}$ \\
\hline Average Worker Wage & $\begin{array}{r}7.830 \mathrm{e}-05^{* * *} \\
(7.75)\end{array}$ & $\begin{array}{r}6.290 \mathrm{e}-05 \\
(1.58)\end{array}$ \\
\hline SD of Worker Wages & $\begin{array}{r}-1.740 \mathrm{e}-05^{*} \\
(-1.94)\end{array}$ & $\begin{array}{r}-1.820 \mathrm{e}-05 \\
(0.51)\end{array}$ \\
\hline Average Worker Age & $\begin{array}{r}-0.006^{* * *} \\
(-4.19)\end{array}$ & $\begin{array}{r}0.007 \\
(1.12)\end{array}$ \\
\hline Average Worker Tenure & $\begin{array}{r}-0.066^{* * *} \\
(-8.53)\end{array}$ & $\begin{array}{r}0.058^{*} \\
(1.89)\end{array}$ \\
\hline $\begin{array}{l}\text { Year Fixed Effects } \\
\text { Industry Fixed Effects }\end{array}$ & $\begin{array}{l}\text { Yes*** } \\
\text { Yes*** }\end{array}$ & $\begin{array}{l}\text { Yes } \\
\text { Yes }\end{array}$ \\
\hline $\begin{array}{l}\text { F-test }(\text { Prob }>\text { chi2 }) \\
\text { Pseudo } R^{2} \\
\text { Observations }\end{array}$ & $\begin{array}{r}0.000 \\
10.5 \% \\
1039365\end{array}$ & $\begin{array}{r}0.859 \\
1.4 \% \\
1520\end{array}$ \\
\hline
\end{tabular}




\section{Table A3: One-to-four Propensity Score Matching}

This table reports difference-in-differences estimates and their associated t-values (in parentheses) from regressions that explain an individual's unemployment incidence using a sample obtained from the one-to-four propensity score matching. The regressions in Columns 1, 7 and 8 use data for buyouts announced between 1999 and 2008 , and the regressions in Columns 2-6 use data for buyouts announced between 2002 and 2008. The percentage change is the coefficient of POST $\times L B O$ divided by the average unemployment incidence, which is defined as the average unemployment incidence for treated workers before $t=1$. The subsamples in Columns 3 and 4 are from Panel B in Table 4, the subsamples in Columns 5 and 6 are from Panel B in Table 5, and the subsamples in Columns 7 and 8 are from Panel D in Table 6 . Statistical significance at the $1 \%$ level is denoted by $* * *$, statistical significance at the $5 \%$ level by $* *$ and statistical significance at the $10 \%$ level by $*$.

\begin{tabular}{|c|c|c|c|c|}
\hline Specification & Baseline 99-08 & Baseline 02-08 & Routine & Non-routine \\
\hline & 1 & 2 & 3 & 4 \\
\hline $\mathrm{POST} \times \mathrm{LBO}$ & $\begin{array}{l}-0.005 \\
(-1.46)\end{array}$ & $\begin{array}{l}-0.002 \\
(-1.48)\end{array}$ & $\begin{array}{r}0.055^{* * *} \\
(-0.56)\end{array}$ & $\begin{array}{r}-0.029 * * * \\
(-3.91)\end{array}$ \\
\hline Average Unemployment Incidence & $11.7 \%$ & $10.9 \%$ & $10.7 \%$ & $16.1 \%$ \\
\hline Percentage Change & $-4.3 \%$ & $-1.8 \%$ & $51.4 \%$ & $-18.0 \%$ \\
\hline$R^{2}$ & $28.2 \%$ & $26.8 \%$ & $24.3 \%$ & $27.6 \%$ \\
\hline Workers & 372175 & 233422 & 14431 & 36350 \\
\hline Observations & 3324902 & 2084913 & 129256 & 324553 \\
\hline \multirow[t]{2}{*}{ Specification } & Offshorable & Non-offshorable & Blue-collar & White-collar \\
\hline & 5 & 6 & 7 & 8 \\
\hline $\mathrm{POST} \times \mathrm{LBO}$ & $\begin{array}{r}0.044^{* *} \\
(3.23)\end{array}$ & $\begin{array}{r}-0.023^{* *} \\
(-3.05)\end{array}$ & $\begin{array}{r}0.012^{*} \\
(1.64)\end{array}$ & $\begin{array}{l}-0.013 \\
(-0.78)\end{array}$ \\
\hline Average Unemployment Incidence & $8.6 \%$ & $16.7 \%$ & $7.5 \%$ & $13.2 \%$ \\
\hline Percentage Change & $51.2 \%$ & $13.8 \%$ & $16.0 \%$ & $-9.8 \%$ \\
\hline$R^{2}$ & $23.2 \%$ & $27.7 \%$ & $38.9 \%$ & $30.8 \%$ \\
\hline Workers & 13452 & 37329 & 19861 & 1657 \\
\hline Observations & 120390 & 333419 & 177842 & 14713 \\
\hline
\end{tabular}




\section{Table A4: Occupation Classifications}

This table details our classification of occupations into routine/non-routine and offshorable/non-offshorable occupations based on Goos et al. (2014). The RTI index measures the routine intensity in an occupation, where a higher value indicates more routine intensity. We define workers in occupations with an RTI index of zero or less as non-routine workers and workers in occupations with a positive RTI value as routine workers. In addition, we define workers in occupations with an offshorability value of zero or less as non-offshorable workers and workers in occupations with positive offshorability values as offshorable workers.

\begin{tabular}{|c|c|c|c|}
\hline Occupation & ISCO-88 code & RTI-Index & Offshorability \\
\hline & 1 & 2 & 3 \\
\hline Managers of small enterprises & 13 & -1.52 & -0.63 \\
\hline Drivers and mobile plant operators & 83 & -1.50 & -1.00 \\
\hline Life science and health professionals & 22 & -1.00 & -0.76 \\
\hline Physical, mathematical, and engineering professionals & 21 & -0.82 & 1.05 \\
\hline Corporate managers & 12 & -0.75 & -0.32 \\
\hline Other professionals & 24 & -0.73 & 0.21 \\
\hline Personal and protective service workers & 51 & -0.60 & -0.94 \\
\hline Other associate professionals & 34 & -0.44 & 0.10 \\
\hline Physical, mathematical, and engineering associate professionals & 31 & -0.40 & -0.12 \\
\hline Life science and health associate professionals & 32 & -0.33 & -0.75 \\
\hline Extraction and building trades workers & 71 & -0.19 & -0.93 \\
\hline Sales and service elementary occupations & 91 & 0.03 & -0.81 \\
\hline Models, salespersons, and demonstrators & 52 & 0.05 & -0.89 \\
\hline Stationary plant and related operators & 81 & 0.32 & 1.59 \\
\hline Laborers in mining, construction, manufacturing, and transport & 93 & 0.45 & -0.66 \\
\hline Metal, machinery, and related trade work & 72 & 0.46 & -0.45 \\
\hline Machine operators and assemblers & 82 & 0.49 & 2.35 \\
\hline Other craft and related trade workers & 74 & 1.24 & 1.15 \\
\hline Customer service clerks & 42 & 1.41 & -0.25 \\
\hline Precision, handicraft, craft printing, and related trade workers & 73 & 1.59 & 1.66 \\
\hline Office clerks & 41 & 2.24 & 0.40 \\
\hline
\end{tabular}



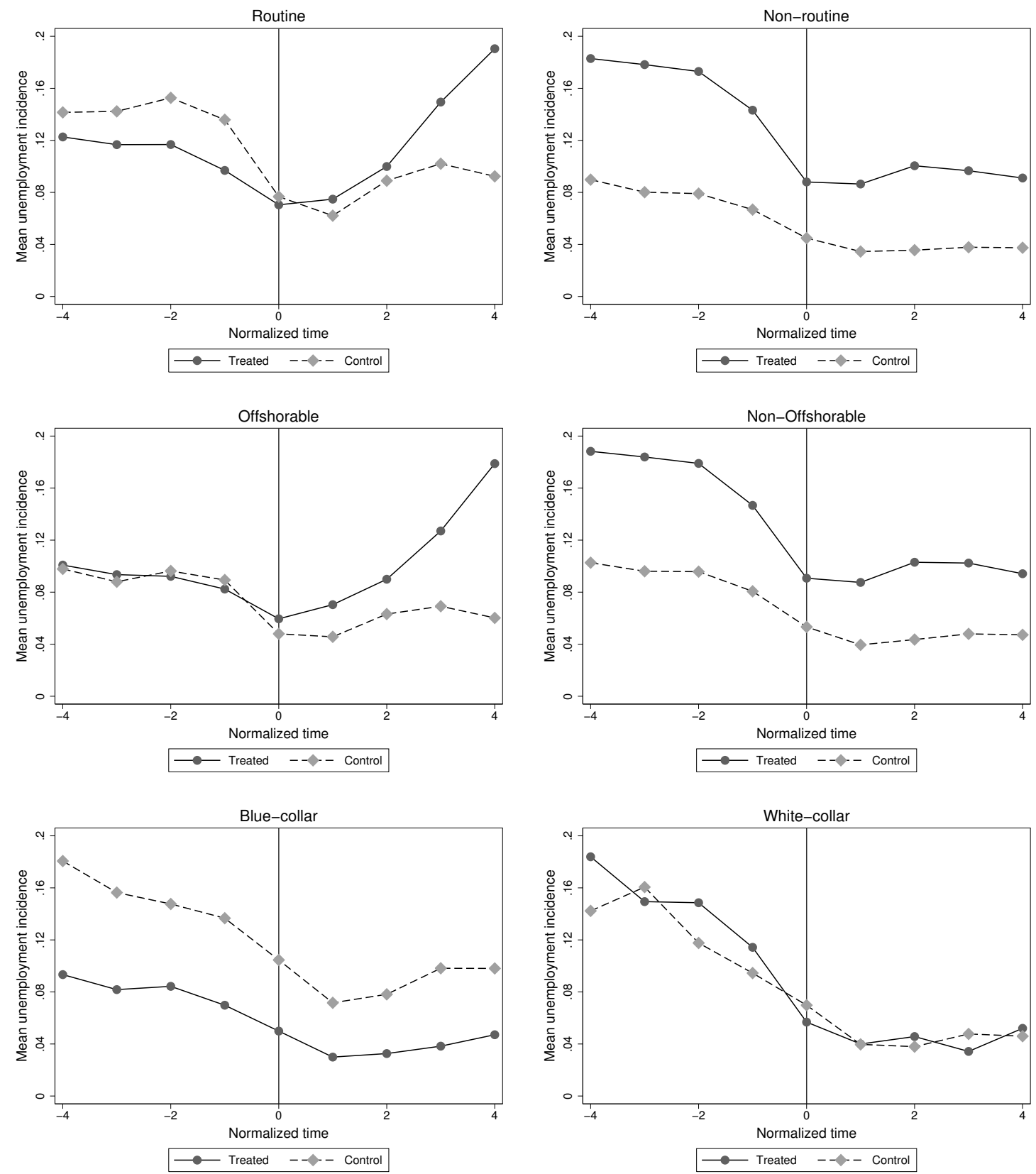

Figure A1: Trends in Unemployment Incidence per Sub-Category

This figure displays the pre-treatment and post-treatment trends in unemployment incidence for subcategories of workers. The subcategories correspond to Panel B in Table 4 (routine/non-routine in the ex ante low-productivity firms), Panel B in Table 5 (offshorable/non-offshorable in the ex ante low-productivity firms), and Panel D in Table 6 (blue-collar/white-collar workers in ex ante low-leverage firms in industries with aggressive labor unions). The buyout is announced at $t=1$. 


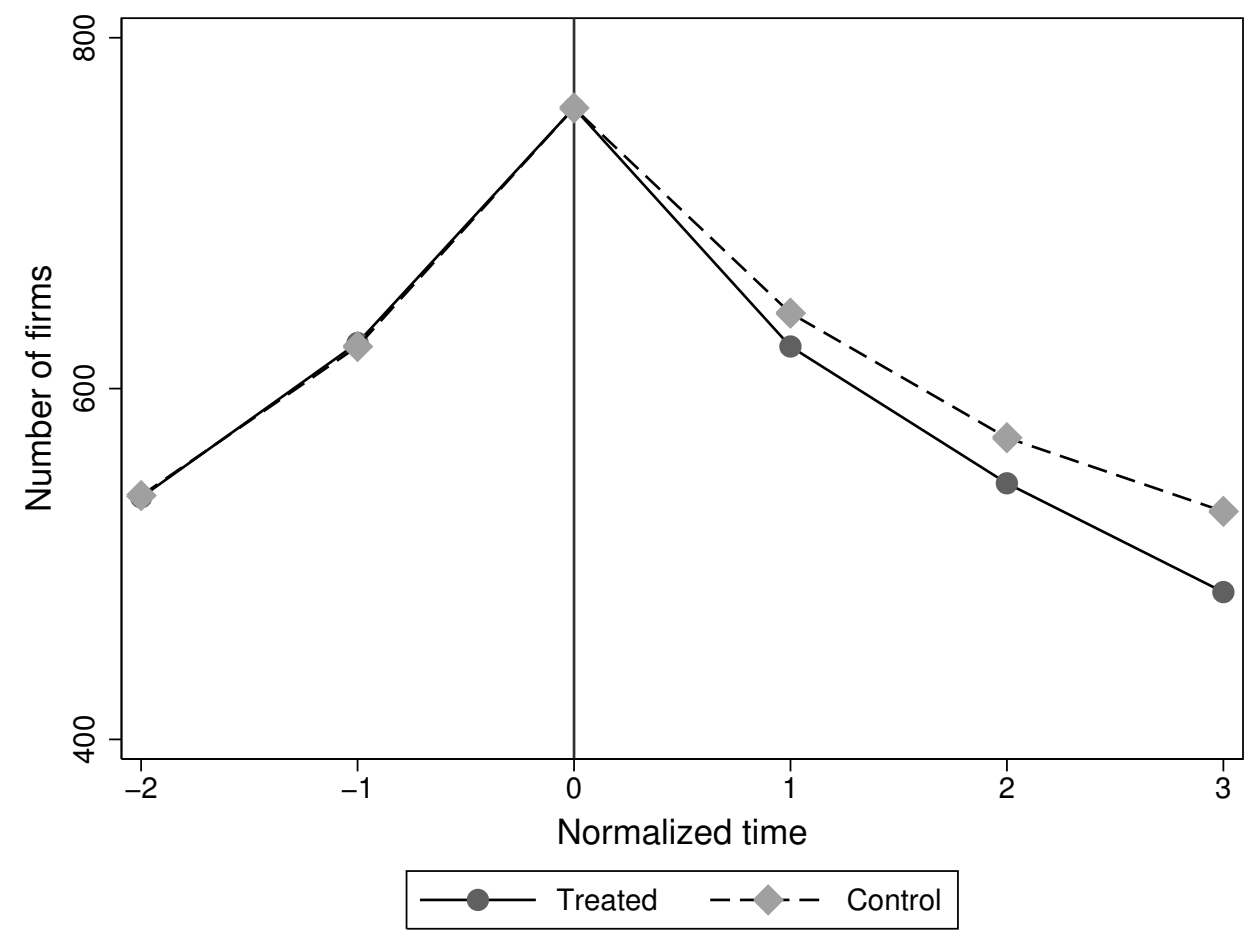

Figure A2: Attrition of Treated and Control Firms

This figure displays the number of treated and control firms over time. The buyout is announced at $t=1$. 